\title{
Antitrust and the Consumer Interest: The Fallacy of Parens Patriae and A Suggested New Approach*
}

\author{
Milton Handler† and Michael D. Blechman†
}

In recent years, a widespread assumption has developed in many quarters that the best way to protect consumers under the antitrust laws is through novel procedural devices which would permit very large numbers of small damage claims to be asserted in massive lawsuits. This view has been reflected in proposals for parens patriae and fluid class actions which have been rejected by the courts, but which are now being considered by the Congress as part of two pending antitrust bills of immense potential importance. ${ }^{1}$

As we shall show, the history of the parens patriae and fluid class innovations and a consideration of how they will function in practice suggest that this approach will neither confer significant benefits on consumers nor provide a workable deterrent for enforcing the antitrust laws in their interest. ${ }^{2}$ Therefore, the time has come to consider alternative means for realizing these objectives. Indeed, a great deal can and should be done to guide and improve antitrust enforcement efforts so that they will produce far more economic benefit for consumers than is the case today.

- The authors gratefully acknowledge the assistance of Barry Schwartz in the preparation of this article.

$\dagger$ Professor of Law Emeritus, Columbia University Law School; Member of N.Y. Bar.

H Member of N.Y. Bar.

1. The bills are H.R. 8532, 94th Cong., 2d Sess. (1975), introduced by Representative Rodino, and its Senate counterpart, S. 1284, 94th Cong., 1st Sess. $\$ \$ 401-05$ (1975), sponsored by Senators Hart and Scott. The Rodino bill has been passed by the House. See 756 Antitrust \& Trade Reg. Rep. (BNA) A-I (1976). The Hart and Scott bill has been reported out of the Judiciary Committee as part of the Antitrust Improvements Act of 1975 .

2. The senior author has commented on this legislation on several previous occasions. See Hearings on the Antitrust Improvements Act of 1975 Before the Subcomm. on Antitrust and Monopoly of the Senate Comm. on the Judiciary, 94th Cong., 1st Sess. 291-306 (1975) (testimony of Milton Handler); Address by Milton Handler, Antitrust-The Scapegoat for The Nation's Ills, Meeting of the Association of the Bar of the City of New York, No. 18, 1975 (on file with Yale Law Journal). Several of the arguments put forth in this article were summarized in Handler, Antitrust-Myth and Reality in an Inflationary Era, 50 N.Y.U. L. REv. 211, 252-56 (1975). 


\section{The Search for a Procedural Panacea}

The effort to develop a procedural device for asserting small individual antitrust claims on behalf of massive groups of consumers had its initial impetus in the 1966 amendments to Rule 23. Prior to that time, a class action for treble damages was in effect a permissive joinder device which required affirmative action by any class member wishing to be represented in the lawsuit. ${ }^{3}$ By virtue of the 1966 amendments, however, each person within the category defined by the plaintiff in his complaint automatically became a member of a litigating class unless he took the steps required by law to "opt out." 4 Thus, the consumer who had little or no financial stake in a lawsuit and who was therefore unlikely to take any action at all would, for that very reason, be included in the class. Consequently, a plaintiff's counsel could purport to represent very large classes with aggregate claims of astronomical dimension simply by drafting appropriate language in a pleading. It is doubtful that the draftsmen intended or even contemplated such results. ${ }^{5}$ Nevertheless, these new possibilities under Rule 23 led to the commencement of suits alleging such prodigious classes as $11 / 2$ million purchasers of bread in Philadelphia, ${ }^{6}$ tens of millions of retail purchasers of gasoline in various states, ${ }^{7} 20$ to 40 million buyers of General Motors automobiles, ${ }^{8}$ 40 million hotel customers, ${ }^{9}$ all homeowners in the United States, ${ }^{10}$ all consumers of eggs in the United States, ${ }^{11}$ and even all 200 million or more persons in the United States. ${ }^{12}$

3. See Notes of Advisory Committee on 1966 Amendment to Rules, Fed. R. Civ. P. 23, 28 U.S.C. app., at $7765(1970)$ [hereinafter cited as Advisory Committee Note]; 3B Moore's Federal Practice ff 23.10[1], 23.12 (2d ed. 1975); Kaplan, Continuing Work of the Civil Committee: 1966 Amendments of the Federal Rules of Civil Procedure (I), 81 HARv. L. RLV. 356, 376, 383.85 (1967).

4. See FED. R. Civ. P. 23(c)(3); Advisory Committee Note, supra note 3, at 7767-68.

5. The Advisory Committee's Note on Rule 23 indicates uncertainty as to whether class actions are appropriate in antitrust cases at all, let alone in the context of treble damage actions brought on behalf of millions of consumers. It states that "[p]rivate damage claims by numerous individuals arising out of concerted antitrust violations may or may not involve predominating common questions." Advisory Committee Note, supra note 3 , at 7767. See Kaplan, supra note 3, at 393.

6. Hackett v. General Host Corp., 1972 Trade Cas. If 73,879 (E.D. Pa. 1970), appeal dismissed, 455 F.2d 618 (3d Cir.), cert. denied, 407 U.S. 925 (1972).

7. City of Philadelphia v. American Oil Co., 53 F.R.D. 45 (D.N.J. 1971).

8. Boshes v. General Motors Corp., 59 F.R.D. 589 (N.D. Ill. 1973).

9. In re Hotel Telephone Charges, 500 F.2d 86 (9th Cir. 1974).

10. Philadelphia Hous. Auth. v. American Radiator \& Standard Sanitary Corp., 50 F.R.D. 13 (E.D. Pa. 1970), aff'd sub nom. Mangano v. American Radiator \& Standard Sanitary Corp., 438 F.2d 1187 (3d Cir. 1971).

11. United Egg Producers v. Bauer Int'l Corp., 312 F. Supp. 319 (S.D.N.Y. 1970).

12. In re Motor Vehicle Air Pollution Control Equipment, 52 F.R.D. 398 (C.D. Cal. 1970), aff'd, rev'd \& remanded in part, 481 F.2d 122 (9th Cir.), cert. denied, 414 U.S. 
As a seeming procedural key for opening up the federal courts to millions of aggrieved consumers, the class action was hailed as "one of the most socially useful remedies in history." 13 In fact, however, the reality never came close to matching the promise of this supposed panacea. As noted by Judge Medina in Eisen v. Carlisle \& Jacquelin, "not a single one of these class actions including millions of indiscriminate and unidentifiable members has ever been brought to trial and decided on the merits." 14 In some instances consumers were found to have suffered no compensable injury. ${ }^{15}$ In other instances the courts refused to certify classes because, among other defects, the sheer burden of processing millions of small claims through discovery and trial rendered the actions unmanageable. ${ }^{16}$ What is more, the supposed

1045 (1973). The subsequent decision in the multidistrict proceedings is reported at 367 F. Supp. 1298 (C.D. Cal. 1973).

13. Pomerantz, New Developments in Class Actions-Has Their Death Knell Bccn Sounded?, 25 Bus. Law 1259, 1259 (1970). See Ash, The Class Action: Solution for th* Seventics, 7 New England L. Rrv. 1 (1971); Berger, Class Actions, 77 Case \& Con., Jan.Feb. 1972, at 26; Freeman, Class Actions From the Plaintiff' T'iewpoint, 38 J. AIR. L. \& Conr. 401, 402-3 (1972); Kohn, The Antitrust Class Action As a Social Instrtument, 41 ANTITRUST L.J. 280 (1972).

14. 479 F.2d 1005, $1018-19$ (2d Cir. 1973), vacated, 417 U.S. 156 (1974). To our knowledge, Judge Medina's observation is still valid.

15. See, e.g., In re Multidist. Vehicle Air Pollution, 481 F.2d 122 (9th Cir.), cert. denied, 414 U.S. 1045 (1973); Philadelphia Hous. Auth. v. American Radiator \& Standard Sanitary Corp., 50 F.R.D. 13 (E.D. Pa. 1970), aff'd sub nom. Mangano v. American Radiator \& Standard Sanitary Corp., 438 F.2d 1187 (3d Cir. 1971); United Egg Producers v. Bauer Int'l Corp., 312 F. Supp. 319 (S.D.N.Y. 1970).

16. See, e.g., In re Hotel Tel. Charges, 500 F.2d 86, 89.92 (9th Cir. 1974) (court calculated that adjudicating claims of even $10 \%$ of class of 40 million hotel guests would take approximately 100 years); Boshes v. General Motors Corp., 59 F.R.D. 589, 599-601 (N.D. Ill. I973) (class of 30 to 40 million automobile purchasers); Cotchett $v$. Avis Rent A Car Sys., Inc., 56 F.R.D. 549, 553-54 (S.D.N.Y. 1972) (class of ov'er 500,000 consumers who paid a surcharge when renting an automobile from defendant car rental agencies); Philadelphia v. American Oil Co., 53 F.R.D. 45, 64-74 (D.N.J. 1971) (class of six million retail consumers of gasoline in Delaware, New Jersey, and Pennsylvania); Reinisch v. NYSE, 52 F.R.D. 561, 563-64 (S.D.N.Y. 1971) (class of over 20 million stockholders); Hackett v. General Host Corp., 1972 Trade Cas. I 73,879, at 91,663, 91,664-65 (E.D. Pa. 1970), appeal dismissed, 455 F.2d 618 (3d Cir.), cert. denied, 407 U.S. 925 (1972) (class of $11 / 2$ million bread purchasers).

Other grounds that have been relied upon by the courts in rejecting consumer class actions have included: (1) the inadequacy of the plaintiff or his counsel as class representative, e.g., Lidie v. California, 478 F.2d 552, 555 (9th Cir. 1973); Graybeal v. American Sav. \& Loan Ass'n, 59 F.R.D. 7, 13-14 (D.D.C. 1973) (plaintiffs' dual roles as attorneys for and representatives of the class found to be in conflict); United Igg Producers $v$. Bauer Int'l Corp., 312 F. Supp. 319, 321 (S.D.N.Y. 1970) (class representative found to have "conflicting and divided [economic] interest"); (2) a lack of predominance of common questions, e.g., In re Hotel Tel. Charges, supra at 88-90; Cotchett v. Avis Rent A Car Sys., Inc., supra at 551-52; and (3) failure to provide the superior method for resolving the dispute in question, e.g., Katz v. Carte Blanche Corp., 496 F.2d 747, 757-63 (3d Cir.), cert. denied, 419 U.S. 885 (1974) (collateral estoppel found to be superior to class action in Truth-in-Lending case where class treatment would compel defendant to assert compulsory counterclaims for debts owed by holders); Graybeal v. American Sav. \& Loan Ass'n, supra at 16 (class action certification would "spawn a proliferation of subclasses"). 
benefits to individual consumers were often so inconsequential that in the view of some courts the attorneys rather than the class members constituted the real parties in interest. ${ }^{17}$

In an effort to meet some of these problems, state parens patriae suits were introduced to the antitrust landscape in the early 1970's.18 Actually, two distinct kinds of parens patriae claims were asserted under quite different legal theories. In the first category, the states sought to extend their traditional powers to protect the interest of idiots, lunatics, and other incompetents by purporting to sue on behalf of their consumer-citizens allegedly injured by a claimed antitrust violation. ${ }^{19}$ The purpose of this kind of action was to allow the states to keep for their own use any unclaimed damages that might be recovered on the consumers' behalf. ${ }^{20}$ Since this procedural in-

17. Sce, e.g., In re Hotel Tel. Charges, 500 F.2d 86 (9th Cir. 1974). In this case the partics agreed that the financial stake of each class member in the litigation was only $\$ 2$ per person, a fact which prompted the court to state:

In view of the nonexistent, or minuscule, recoveries that are likely to accrue to the supposedly intended beneficiaries, it is not surprising that most of the named plaintiffs are attorneys acting as counsel for themselves. . . [T]his action has been primarily generated and financially supported by the lawyers who possibly stand to realize astronomical fees, and not by the individuals whose potential claims in any event are de minimis. ...

Id. at 91. See also Cotchett v. Avis Rent A Car Sys., Inc., 56 F.R.D. 549, 553-54 (S.D.N.Y. 1972 ).

18. See Hawaii v. Standard Oil Co., 301 F. Supp. 982 (D. Hawaii 1969), rev'd, 431 F.2d 1282 (9th Cir. 1970), aff'd, 405 U.S. 251 (1972); Philadelphia Hous. Auth. v. American Radiator \& Standard Sanitary Corp., 309 F. Supp. 1057 (E.D. Pa. 1969) (California and Kansas); City of Philadephia v. American Oil Co., 53 T.R.D. 45, 48, 67 (D.N.J. 1971) (New Jersey); In re Antibiotic Antitrust Actions, 333 F. Supp. 278 (S.D.N.X. 1971) (California, Hawaii, Kansas, Oregon, Utah, and Washington); In re Motor Vehicle Air Pollution Control Equip., 52 F.R.D. 398, 401 (C.D. Cal. 1970), aff'd in part, rev'd i remanded in part on ather grounds, 481 F.2d 122 (9th Cir.), cert. denied, 414 U.S. 1045 (1973) (New Jersey, Illinois, and New York); California v. Frito-Lay, Inc., 333 F. Supp. 977 (C.D. Cal. 1971), rev'd, 474 F.2d 774 (9th Cir.), cert. denied, 412 U.S. 908 (1973).

The initial impetus for these parens patriae antitrust suits was probably in large part judicial approval of a settlement device agreed to by various defendant drug companies in West Virginia v. Chas. Pfizer \& Co., 314 F. Supp. 710 (S.D.N.Y. 1970), aff'd, 440 F.2d 1079 (2d Cir.), cert. denied, 404 U.S. 871 (1971). Under this plan, the states were to be used as conduits for consumer recoveries, settling the claims of the states as parens palriae on behalf of their citizens. 314 F. Supp. at 722-23, 728.

19. This was the type of parens patriae claim originally asserted in Hawaii v. Standard Oil Co., 301 F. Supp. 982, 984 n.4 (D. Hawaii 1969), rev'd on other grounds, 431 F.2d 1282 (9th Cir. 1970), aff'd, 405 U.S. 251 (1972). See note 21 infra. For additional cases, sce In re Motor Vehicle Air Pollution Control Equip., 52 F.R.D. 398, 401 (C.D. Cal. 1970), aff'd in part, rev'd \& remanded in part on other grounds, 481 F.2d 122 (9th Cir.), cert. denied, 414 U.S. 1045 (1973); California v. Frito-Lay, Inc., 333 F. Supp. 977 (C.D. Cal. 1971), rev'd, 474 F.2d 774 (9th Cir.), cert. denied, 412 U.S. 908 (1973); Philadelphia Hous. Auth. v. American Radiator \& Standard Sanitary Corp., 309 F. Supp. 1057 (E.D. Pa. 1969). The historical roots of this branch of parens patriae in the powers of the English King to protect the rights of incompetents are traced in Malina \& Blechman, Parens Patriae Suits for Treble Damages under the Antitrtst Laws, 65 Nw. U. L. REv. 193, 197202, 212-19 (1970).

20. The states had been allowed to keep unclaimed damages in a settlement in West 
novation circumvented all of the safeguards of Rule 23, it not surprisingly received short shrift in the courts. ${ }^{21}$ Moreover, just as the appointment of a guardian ad litem does not change the substantive rights of an incompetent party, ${ }^{22}$ this type of parens patriae could not in any event obviate the need to prove individual injury to each consumer on whose behalf suit was brought.

To overcome this obstacle, a second type of parens patriae action was devised which attempted to avoid the need for proving damages to individuals by relying instead on putative injury to the so-called general economy of the state itself. ${ }^{23}$ This second category of parens patriae was rejected by the Ninth Circuit in Hawaii v. Standard Oil of California $a^{24}$ on the ground that the "general economy" of a state is an "abstraction" which the court doubted could be the subject of independent harm. The Supreme Court affirmed, pointing out, among other things, that "[a] large and ultimately indeterminable part of the injury to the 'general economy' . . . is no more than a reflection of injuries to the 'business or property' of consumers . . . ."25

Virginia v. Chas. Pfizer \& Co., 314 F. Supp. 710 (S.D.N.Y. 1970), aff'd, 440 F.2d 1079 (2d Cir.), cert. denied, 404 U.S. 871 (1971). In California v. Frito-Lay, Inc., 474 F.2d 774, 776 (9th Cir.), cert. denied, 412 U.S. 908 (1973), California, as parens patriae, sought to recover on behalf of its 20 million consumers of snack foods. The court pointed out that "[t]he state [was] looking beyond recovery for injuries to its citizens to its own ultimate acquisition of the recoveries obtained."

21. See California v. Frito-Lay, Inc., 474 F.2d 774 (9th Cir.), cert. denied, 412 U.S. 908 (1973) (expressing concern over the need for procedural safeguards); In re Motor Vehicle Air Pollution Control Equip., 52 F.R.D. 398, 401 (C.D. Cal. 1970), aff'd in part, rev'd \& remanded in part on other grounds, 481 F.2d 122 (9th Cir.), cert, denied, 414 U.S. 1045 (1973); Philadelphia Hous. Auth. v. American Radiator \& Standard Sanitary Corp., 309 F. Supp. 1057 (E.D. Pa. 1969) (parens patriae suits would lack the procedural safeguards provided by Rule 23). Even in Hawaii v. Standard Oil Co., 301 F. Supp. 982 (D. Hawaii 1969), rev'd, 431 F.2d 1282 (9th Cir. 1970), aff'd, 405 U.S. 251 (1972), where the district court initially approved the state's parens patriae claims based on an alleged injury to the economy of Hawaii as a whole, Judge Pence rejected parens patriae claims for injury to its individual consumers. He noted and reaffirmed this unreported decision at $30 \mathrm{I}$ F. Supp. at 984 n.4, 986-87. Indeed, to the extent that Judge Pence approved Hawaii"s parens patriae claims, he stressed that he was doing so on the basis that the alleged injury was separate and apart from that of the state's consumers. $301 \mathrm{~F}$. Supp. at 986-88.

22. "A guardian ad litem is a fiduciary whose scope is very limited. . . . His functions are [only] to provide counsel for his ward and see that the ward's rights are protected in the conduct of the suit." 25 N.Y. JuR., Guardian $\&$ Ward $\$ 76$, at 339 (1962).

23. See Hawaii v. Standard Oil Co., 301 F. Supp. 982 (D. Hawaii 1969), rev'd, 431 F.2d 1282 (9th Cir. 1970), aff'd, 405 U.S. 251 (1972), where Hawaii included this type of parens patriae claim in its fourth amended complaint, after the court had dismissed its cause of action based on the first type of parens patriae involving claims for injury to its individual consumers. This second type of parens patriae, arising out of the nature of the federal system, is discussed in Malina \& Blechman, supra note 19, at 202-12.

24. 431 F.2d 1282, 1285 (9th Cir. 1970), aff'd, 405 U.S. 251 (1972).

25. 405 U.S. at 264. After the Supreme Court's decision in the case, Hawaii settled with the oil company defendants, dismissing the suit in return for the defendants' payment of the $\$ 185,000$ in attorneys' fees incurred in four years of litigation. See 593 Antrtrust \& Trade Reg. Rep. (BNA) A-18 (1972). 
The final judicial innovation for circumventing the problems of asserting treble damage claims based on supposed injuries to consumers was the "fluid class" device proposed by the plaintiff and accepted by the district court in Eisen $v$. Carlisle of Jacquelin. ${ }^{26}$ That case involved an alleged class of some 6 million odd-lot traders on the New York Stock Exchange who were estimated to have been overcharged an average of $\$ 1.30$ per class member for brokerage services during the relevant period. ${ }^{27}$ As might have been expected in view of the modest stakes involved for each individual investor, "[n]o claimant in the six years of the progress of the action had shown any interest in Eisen's claim." 28

The district court had initially held the class action unmanageable because of the large size of the class and the minuscule size of the individual claims. ${ }^{29}$ On remand from the court of appeals, ${ }^{30}$ it adopted a "fluid recovery" procedure under which damages would be awarded in the aggregate to "the class as a whole." ${ }_{1} 1$ Those persons actually injured and wishing to file claims (which were expected to be relatively few in number) were to be paid out of the fund created by the aggregate damage recovery. The remainder of the fund would be disbursed by reducing future odd-lot brokerage fees by some judicially set amount until the fund was depleted-in effect distributing the "excess" damage recovery to future odd-lot purchasers, regardless of whether or not such persons had bought during the alleged conspiracy and therefore even arguably had suffered some injury. ${ }^{32}$

The Second Circuit rejected this innovation, not merely because of the violence it did to Rule 23 , but also "as an unconstitutional violation of the requirement of due process of law."33 If constitutional requirements were observed, the court noted, the alleged class would be unmanageable and the costs of processing individual claims would render the amounts payable to individual class members "so low as to be negligible." 34

26. 52 F.R.D. 253 (S.D.N.Y. 1971), rev'd, 479 F.2d 1005 (2d Cir. 1973), vacated, 417 U.S. 156 (1974). The class action determination in this litigation had a long and tangled history. See, e.g., Dam, Class Action Notice: Who Needs It?, 1974 Sup. Cr. Rev. 97, 100-03.

27. 479 F.2d at 1010 .

28. Id.

29. 41 F.R.D. 147 (S.D.N.X. 1966), rev'd, 391 F.2d 555 (2d Cir. 1968).

30. The Second Circuit reversed the district court's denial of the class and remanded the case for an evidentiary hearing "on the questions of notice, adequate representation, effective administration of the action," and other matters deemed proper. 391 F.2d 555, 570 (2d Cir. 1968).

31. 52 F.R.D. at 264.

32. Id. at 264-65.

33. $479 \mathrm{~F} .2 \mathrm{~d}$ at 1018 .

34. Id. at 1017. The Supreme Court upheld the Second Circuit's decision, but limited 
Having come to a dead end in the courts, the search for a procedure to vindicate small consumer claims in antitrust suits moved to the Congress. One bill recently passed by the House and another presently pending in the Senate would adopt through legislation the devices of parens patriae and fluid class suits rejected in the courts. ${ }^{35}$ The proposed legislation would empower the attorney general of any state to bring parens patriae suits for damages sustained by natural persons residing in the state. ${ }^{36}$ The bills further provide that in parens patriae suits asserting the individual damage claims of state residents, "damages may be proved and assessed in the aggregate" using unspecified statistical, sampling, and other estimating methods; while the Senate bill would extend this provision to all class actions brought under the antitrust laws on behalf of natural persons, the corresponding section of the House bill is limited to class actions brought by states. ${ }^{37}$ Neither bill indicates what is to happen in class actions after such an "aggregate" damage fund is created. The legislation does provide, however, that in parens patriae suits the court shall have discretion to dictate a method of distribution unless a method is specified by state law, with the caveat that each of the purportedly injured

its discussion to the narrow ground of notice. 417 U.S. 156 (1974). The Court held that individual notice had to be sent to all class members who could be identified through reasonable efforts, and that the cost of such notice-cstimated at $\$ 315,000-$ had to be borne by the plaintiff. Since Eisen's own financial stake in the lawsuit was at most $\$ 70$, as a practical matter this ruling marked the end of the lawsuit as a class action. For a discussion of the ethical problems of having counsel pay the costs of notice where it is uneconomical for plaintiff himself to do so, see Robinson, Recent Antitrust Developments-1974, 30 RECORD OF N.Y.C.B.A. 142, 169-71 (1975).

35. H.R. 8532, 94th Cong., 2d Scss. (1975); S. 1284, 94th Cong., Ist Sess. $\$ \$ 401.05$ (1975). See note 1 supra.

36. H.R. 8532, 94th Cong., 2d Sess. $\$ 2(4 C)$ (a) (1975), provides:

Any State attorney general may bring a civil action, in the name of the State, in the district courts of the United States under section 4 of [the Clayton] Act, and such State shall be entitled to recover threefold the damages and the cost of suit, including a reasonable attorney's fee, as parens patriae on behalf of natural persons residing in such State injured by any violation of the Sherman Act.

Similarly, S. 1284, 94th Cong., lst Sess. $\$ 401(4 C)(a)(1)(1975)$, states:

Any attorney general of a State may bring a civil action in the name of such State in any district court of the United States having jurisdiction of the defendant, to secure monetary and other relief as provided in this section in respect of any damage sustained, by reason of the defendant's having done anything forbidden in the Sherman Act, by-

(A) the natural persons residing in such State, or any of them ....

In addition, under the House bill, a parens patriae action initially brought on behalf of natural persons could be converted into a class action. In such a class action the state attorney general could conceivably represent a class of plaintiffs including business entities and natural persons if they both had been injured in exactly the same manner. See H.R. 8532, 94th Cong., 2d Sess. $\$ 2(4 \mathrm{C})$ (b) (1975); House Comm. on the JudiciarY, Report on Antitrust Parens Patriae Act, H.R. Rer. No. 499, 94th Cong., 1st Sess. 10 (1975) [hereinafter cited as 1975 REPORT].

37. See H.R. 8532, 94th Cong., 2d Sess. $\$ 2(4 D)$ (1975); S. 1284, 94th Cong., lst Sess. $\S 401(4 C)(c)(1)(1975)$. 
natural persons on whose behalf suit was brought shall have a reasonable opportunity to secure his "appropriate portion" of the fund. ${ }^{38}$ Thus, the pending legislation would permit precisely the kind of "fluid recovery" procedure which the Second Circuit rejected in Eisen.

The foregoing history suggests that the development of the fluid recovery and parens patriae devices has been predicated upon certain assumptions of questionable validity. The first is that the problems of proof of injury and manageability which render consumer class actions unworkable are mere technical difficulties that may be overcome by legal ingenuity. Supporters of the proposed legislation seem to assume that judicial rejection of parens patriae and fluid classes has been based on precedential or doctrinal grounds that may be legislatively overruled. ${ }^{39}$ A second, more important assumption helps explain the persistent conviction that, despite all problems, some means must be found to provide an effective consumer treble damage remedy. This is the view that, in any given case, the defendants have gouged the public and wrongfully extracted from consumers a "pot of gold" which now lies secreted in their corporate coffers. ${ }^{40} \mathrm{It}$ is assumed that justice requires that some way be found to get the consumer back his money or, if that is impossible, at least to make the defendants disgorge their illegal profits and deter others from similar violations.

In order to determine the extent to which these assumptions are justified, it is useful to consider how the proposed legislation will

38. H.R. 8532, 94th Cong., 2 d Sess. $\$ 2(4 \mathrm{E})$ (1975); S. 1284, 94th Cong., 1st Sess. $\S 401$ $(4 \mathrm{C})(\mathrm{c})(2)(1975)$.

39. See, e.g., 1975 REPORT, supra note 36, at 8:

The thrust of the bill is to overturn [California v. Frito-Lay, Inc., 474 F.2d 774 (9th

Cir.), cort. denied, 412 U.S. 908 (1973)] by allowing State attorneys general to act as consumer advocates in the enforcement process, while at the same time avoiding the problems of manageability which some courts have found under Rule 23.

The debates before the entire House reveal the same attitude. Representative Badillo, for example, was firmly of the view that "this legislation clarifies what had been the law until the recently held Frito-Lay case." 122 Conc. Rec. H2067 (daily ed. Mar. 18, 1976). He stated:

The Supreme Court long ago recognized that States, in the person of their highest legal officer, could sue as parens patriae on behalf of consumers within that State for injunctive and other equitable remedies. These suits naturally included injuries sustained by the consumer as a result of illegal price fixing and other antitrust violations.

Id. In fact, parens patrine has been rejected on every occasion in which it has been asserted in an antitrust context, with the sole exception of Georgia v. Pennsylvania R.R., 324 U.S. 439 (1945), which was emphatically not a suit brought on behalf of consumers. The Georgia case was an action to vindicate the quasi-sovereign interests of Georgia itself in putting an end to a conspiracy to discriminate in favor of the ports of sister states, i.c., a conspiracy aimed at the state as such. See Malina \& Blechman, supra note 19, at 210-12. The courts have been unanimous in rejecting supposed quasi-sovereign parens patriae actions that are really for the benefit of individual citizens such as consumers. See id.

40. See, e.g., In re Antibiotic Antitrust Actions, 333 F. Supp. 278, 282-83 (S.D.N.Y. 
actually work when applied to the kinds of antitrust violations that are occurring in the economy today. In order to do this, we have examined the Commerce Clearing House Reports for the past five years describing the 346 civil and criminal actions commenced during that time by the Department of Justice. ${ }^{41}$ These Reports provide a unique source of information about the suits brought by the Government (which, in turn, reflect the Antitrust Division's perception of existing violations warranting government action). Moreover, the Reports constitute the best available universe for any statistical study of antitrust enforcement. ${ }^{42}$ This body of data is particularly relevant for present purposes since the proponents of the pending parens patriae bills themselves rely upon the record of recent Justice Department actions

1971); Eisen v. Carlisle \& Jacquelin, 52 F.R.D. 253, 264 (S.D.N.Y. 1971), rev'd, 479 F.2d 1005 (2d Cir. 1973), vacated, 417 U.S. 156 (1974). That this same preconception is shared by the proponents of the pending legislation is readily apparent in Hearings on Antitrust Parens Patriae Amendments Before the Subcomm. on Monopolies and Commercial Law of the House Comm. on the Judiciary, 94th Cong., lst Sess. (1975) [hereinafter 1975 Hearings on Parens Patriae Amendments]. For example, the sponsor of the House bill, Representative Rodino, rhetorically asked a witness:

[W] ould you agree that in order to reach some of these actions that are being taken that either go unchallenged or unchecked and where you cannot employ the class action and there is this price fixing and this conspiracy and someone is enriched in such a manner that people cannot rest unless there is some attempt to correct the situation? It distorts the economy, it has an unjust effect on society such that there ought to be some kind of a vehicle which might be employed, of course, with all due regard to the necessary constitutional rights being preserved for all parties. Id. at 53. See id. at 63 (Rep. Railsback's statement to the same witness).

4I. 5 TRADE REG. REP. Tf 45,071-75 (1976). This looseleaf service summarizes all antitrust complaints, indictments, and informations. It also reports on the progress and disposition of these suits.

42. See Posner, A Statistical Sludy of Antitrust Enforcement, 13 J. Law \& EcoN. 365 (1970).

The total statistical universe of government and private antitrust suits would yield substantially the same results, since treble damage actions tend to follow in the wake of government actions. For example, of the $\mathbf{8 8 0}$ private antitrust cases commenced during 1961-1963 (the most recent period for which such data are presented to Professor Posner), 759 were preceded by Justice Department judgments. Id. at 372 . Indeed, not only private parties but also states must rely upon the Antitrust Division as the agency primarily responsible for detecting antitrust violations-a fact which is recognized in the provisions in the pending bills requiring the Attorney General of the United States to notify state attorneys general of suits in which the states might have causes of action. See H.R. 8532, 94th Cong., 2d Sess. $§ 2(4 F)$ (1975); S. 1284, 94th Cong., Ist Sess. $\S 401$ (4D) (1975).

The record of private suits also tends to be more misleading from a statistical standpoint than the record of government prosecutions. As Professor Posner points out:

[A] single antitrust violation may give rise to many private suits, for there is usually more than one victim of a monopolistic practice. The 2,233 electrical equipment cases noted in Table 3 arose from a few indictments. One does not know how many separate violations have been attacked by private suits; it may be only a small Id. fraction of the total number of private antitrust cases.

In short, while the record of Justice Department prosecutions may not reflect in their exact proportions the antitrust violations actually occurring in the economy, there is no reason to doubt that the general categories of suits brought are representative. 
to prove what they believe to be the need for the remedial legislation. ${ }^{43}$

As we examine the cases brought during the last five years, we will see that the proposed legislation is predicated on a false conception of the kinds of antitrust violations occurring in the economy, their impact on consumers, and the likely effects of a parens patriae remedy. We turn first to the vast majority of cases where antitrust violations have occurred at levels in the chain of distribution so remote from consumers as to make it virtually impossible for them either individually or as a class to prove that they suffered any compensable injury at all, much less the amount of their alleged damages. Such cases are further complicated by the fact that multiple, conflicting claims are typically asserted by persons at different levels in the chain of distribution based on the same alleged overcharge. As we shall show, neither the parens patriae nor fluid recovery devices provide solutions to the very real problems of proof of injury and manageability presented by these cases.

Next, we will examine the relatively small number of alleged price-fixing conspiracies in which consumers are directly affected, and where the new legislation therefore might have an impact. We shall show that the nature of both the violations and the defendants involved in such cases bears little resemblance to the stereotypes apparently envisioned by the proponents of the pending bills. What is more, there is a welter of practical, policy, and constitutional objections which render parens patriae inadequate both as a deterrent and as a compensatory remedy even in the few cases where it has potential application.

An analysis of the inadequacies of the proposed legislation, however, does not solve the problem of how the antitrust laws may best be enforced to benefit consumers. Therefore, in the final section of this article, we shall suggest some alternative solutions which we believe will help to realize the objectives of the pending bills far more effectively and without the problems raised by parens patriae and fluid class actions.

\section{Antitrust Violations Affecting Consumers Indirectly}

It is clear that many of the proponents of parens patriae envision the typical antitrust violation as a price-fixing conspiracy in which overcharges are exacted by the defendants in sales to consumers. ${ }^{44}$

43. See, e.g., 1975 REPORT, supra note 36 , at 4.

44. See, e.g., 75I ANTitrust \& TRAde Reg. Reporr (BNA) A-3 (1976), quoting letter 
In fact, however, of the 346 government cases brought in the past five years, horizontal price-fixing at the retail level was alleged in only 45 (by no means all of which actually resulted in overcharges to consumers ${ }^{45}$ ); and the farther one moves from retail price-fixing, the more problematical and difficult it becomes to prove injury to consumers.

\section{A. Horizontal Price-Fixing}

Even in the general area of horizonal price-fixing, with its typical element of overcharge, the great majority of government suits involves conspiracies which affect consumers, if at all, only in a very indirect manner. ${ }^{46}$ In most of these-cases the price-fixed item is a minor component of the product or service that the consumer purchases. For example, many of these suits have involved items such as gypsum wall board and plaster, ${ }^{47}$ gas vent pipe, ${ }^{48}$ plastic pipe fittings, ${ }^{49}$ concrete ${ }^{50}$ and concrete block, ${ }^{51}$ toilet seats, ${ }^{52}$ and overhead garage doors ${ }^{53}$-items which consumers typically acquire only as component parts of new or used houses. Similarly, the Department has charged price-fixing conspiracies affecting zipper sliders, ${ }^{54}$ which con-

from Representative Rodino to House Rules Committee, Feb. 6, 1976; 122 Conc. Rrc. H2062-63 (daily ed. Mar. 18, 1976) (Rep. Rodino).

45. See pp. 659-60 infra. Horizontal price-fixing involves agreements among competitors.

46. Of the 192 horizontal price-fixing cases the Government has brought in the past five years, 134 involved conspiracies in areas of the private economy far removed from the consumer. We shall focus on these cases in this section. Another thirteen alleged the rigging of bids to federal, state, and local governments. To the extent that a government sells services (such as municipal utilities), the injury to the consumer in these thirteen cases is much like that resulting from remote violations in the private sector. To the extent that the overcharge is paid out of general revenues, proof of injury to consumers as taxpayers may be even more difficult.

47. United States v. United States Gypsum Co., 5 Trude Reg. ReP. $\int 45,073$ (Cas. Nos. 2356, 2357) (W.D. Pa., D.D.C. 1975) (dispositions noted); id. If 45,071 (Cas. No. 2204) (N.D. Cal., filed Dec. 30, 1971).

48 United States v. American Metal Prods. Corp., 5 Trade Reg. Rep. If 45,073 (Cas. No. 2343) (C.D. Cal. 1973).

49. United States v. R \& G Sloane Mfg. Co., 5 Trade Reg. Rep. If 45,071 (Cas. Nos. 2179, 2180) (C.D. Cal., filed June 29, 1971) (dispositions noted).

50. United States v. Monroc, Inc., 5 TRADE REg. REP. If 45,075 (Cas. Nos. 2481-2484) (D. Idaho, indictment returned Oct. 16, 1975); United States v. Jahncke Serv., Inc., 5 Trade Reg. ReP. $\{45,073$ (Cas. No. 2305) (E.D. La. 1973).

51. United States v. Ampress Brick Co., 5 Trade Reg. Rrp. I 45,073 (Cas. Nos. 2315, 2316) (N.D. Ill., indictment returned Apr. 19, 1973).

52. United States v. Beatrice Foods Co., 5 Trade REg. Rrp. T 45,074 (Cas. Nos. 2391, 2392) (E.D. Mich. 1975) (dispositions noted).

53. United States v. Overhead Door Distribs. Ass'n, 5 Trade Rec. Rer. I 45,072 (Cas. Nos. 2211-2214) (E.D. Pa., indictment returned Jan. 27, 1972) (dispositions noted).

54. United States v. Slide-Rite Mffg. Corp., 5 Trade Reg. ReP. If 45,074 (Cas. Nos. 2407, 2408) (S.D.N.Y., indictment returned Sept. 10, 1974) (dispositions noted). 
sumers ultimately acquire as part of the clothing they purchase, ${ }^{55}$ and paper labels, which are put on some bottles and cans and thus purchased as a minor incident to food and beverages. ${ }^{56}$ Even further removed from consumers are the conspiracies charged by the Government affecting the prices of, for example, diamond grit used for industrial grinding, ${ }^{57}$ chromite sand used to make molds for steel ingot, ${ }^{58}$ nylon netting used for shrimp and salmon fishing, ${ }^{59}$ and chemicals used to make plastics ${ }^{80}$ and herbicides, ${ }^{61}$ all of which have only the most speculative effect on the prices of goods or services actually sold to consumers. ${ }^{62}$ On the other hand, in another group of cases involving local price-fixing conspiracies by wholesalers of bread, ${ }^{63}$ dairy products, ${ }^{64}$ meat, ${ }^{65}$ eggss, ${ }^{66}$ and produce, ${ }^{67}$ consumers do purchase the price-fixed items as such, but only after they have been bought and sold at one or more intervening levels in the chain of distribution.

55. For a brief description of the chain of distribution of zipper sliders, sec Judge Carter's opinion in Carnivale Bag Co. v. Slide-Rite Mfg. Co., 395 F. Supp. 287, 289 (S.D.N.Y. 1975).

56. United States v. H.S. Crocker Co., 5 TRADE Reg. Rep. If 45,074 (Cas. Nos. 2372-2374) (N.D. Cal,, indictment returned Mar. 12, 1974); United States v. Litton Business Sys., Inc., 5 Trade Reg. Rer. $\llbracket 45,074$ (Cas. No. 2388) (N.D. Cal., filed June 7, 1974) (dispositions noted).

57. United States v. DeBecrs Indus. Diamond Div., Ltd., 5 Trade Reg. ReP. If 45,074 (Cas. Nos. 2425, 2426) (S.D.N.Y., indictment returned Dec. 10, 1974).

58. United States v. Combustion Eng'r, Inc., 5 'Trade Reg. ReP. ff 45,073 (Cas. Nos. 2348, 2349) (E.D. Pa. 1974) (dispositions noted).

59. United States v. Brownell \& Co., 5 Trade Reg. Rel. If 45,072 (Cas. Nos. 2289-2293)

(N.D. Ala. 1973, 1974; W.D. Tenn. 1973, 1976) (dispositions noted).

60. United States v. FMC Corp., 5 Trade RfG. Rer. I 45,075 (Cas. Nos. 2446, 2447) (D. Mass., indictment returned Mar. 21, 1975).

61. United States v. American Hocchst Corp., 5 Trude Rrg. Rer. I 45,075 (Cas. No.

2457) (S.D.N.Y. 1975) (disposition noted).

62. Sce, e.g., note 77 infra.

63. United States v. ITT Continental Baking Co., 5 Trade Reg. Rep. $\int 45,075$ (Cas. Nos. 2465, 2466) (S.D. Cal., indictment returned June 24, 1975) (disposition noted); United States v. Kahn's Bakery, Inc., 5 Trade Reg. Rep. If 45,075 (Cas. Nos. 2455, 2456) (W.D. Tex. 1975) (dispositions noted); United States v. Ideal Baking Co., 5 Trade REg. REP. If 45,075 (Cas. Nos. 2433A-2440) (E.D. La., indictment retumed Feb. 28, 1975) (dispositions noted); United States v. Rainbo Baking Co., 5 Trupl: Rve. Rre. If 45,074 (Cas. Nos. 2368, 2369) (D. Ariz. 1974) (dispositions noted); United States v. Gonnclla Baking Co., 5 Tride Reg. Rep. if 45,072 (Cas. Nos. 2280, 2981) (N.D. Ill. 1972) (dispositions noted); United States v. Sweetheart Bakers, Inc., 5 Trude Rig. Rer. If 45,07i (Cas. Nos. 2182-2185) (D. Mdd. 1972) (dispositions noted).

64. United States v. Borden, Inc., 5 Tr.10E RLg. Rer. fi 45,074 (Cas. Nos. 2402, 2403) (D. Ariz. 1974) (dispositions noted); United States v. Arden-Mayfair, Inc., 5 Trad REg. REP. I 45,071 (Cas. Nos. 2189, 2190) (W.D. Wash. 1972) (dispositions noted).

65. United States v. Blue Ribbon Meat Co., 5 Tride Reg. Rer. II 45,072 (Cas. Nos. 2278, 2279) (D. Nev., filed Sept. 12, 1972) (dispositions noted).

66. United States v. Countryside Farms, Inc., 5 Trade Rec. Rep. If 45,075 (Cas. Nos. 2470,2471 ) (D. Utah, indictment returned July 28, 1975).

67. United States $v$. A. Levy \& J. Zentner Co., 5 Trade Reg. Rer. đ 45,072 (Cas. Nos. 2274, 2275) (D. Nev, indictment returned Aug. 15, 1972) (dispositions noted). 


\section{The Problem of Proving Pass-On}

The problem in all of the situations in which the consumer does not deal directly with an alleged price-fixer is that he cannot establish a claim merely by proving that an antitrust violation has occurred; rather, in order to show that he has been injured, the consumer must also demonstrate that an overcharge reached him by being passed from one level to another in the chain of distribution.

The extreme (indeed, insuperable) difficulty of providing adequate proof of the pass-on of an overcharge was articulated by Justice White in his now classic opinion in Hanover Shoe, Inc. v. United States Shoe Machinery Corp. ${ }^{88}$ The plaintiff in that case was a shoe company which claimed that the defendant's unlawful policy of leasing, as opposed to selling, its shoe manufacturing machinery had raised the total cost plaintiff paid for use of the machinery in question. ${ }^{69}$ By way of defense, the defendant argued that the plaintiff had suffered no injury since it had "passed-on" any overcharge to its own customers by increasing the prices at which it sold shoes.

In rejecting this defense, the Court stressed the virtual impossibility of establishing a causal link between an overcharge incurred by a business in acquiring supplies or equipment and the pricing decisions of that company's executives in the different and presumably competitive market in which it sells. Justice White noted:

Normally the impact of a single change in the relevant conditions cannot be measured after the fact; indeed a businessman may be unable to state whether, had one fact been different (a single supply less expensive, general economic conditions more buoyant, or the labor market tighter, for example), he would have chosen a different price. ${ }^{70}$

Indeed, even in the best possible circumstances, where "it could be shown that the buyer raised his price in response to, and in the amount of, the overcharge," it would still be impossible to prove

68. 392 U.S. 481 (1968).

69. In an earlier government suit, United had been found to have monopolized the market for shoe manufacturing machinery. See United States v. United Shoe Mach. Corp., 110 F. Supp. 295 (D. Mass. 1953), aff'd per curiam, 347 U.S. 521 (1954). The Supreme Court agreed with plaintiff Hanover Shoe that United's practice of leasing and refusing to sell its major machines had been held illegal in this prior suit, making the prior judgment prima facie evidence of liability under $\$ 5(a)$ of the Clayton Act, 15 U.S.C. $\$ 16(a)$ (Supp. IV 1974). 392 U.S. at 483-87. Hanover Shoe claimed damages measured by the difference between what it paid the defendant for leasing the machines and the price it would have paid had it been able to purchase them.

70. Id. at $492-93$. 
that the buyer's price increase represented the pass-on of that overcharge since

there would remain the nearly insuperable difficulty of demonstrating that the particular plaintiff could not or would not have raised his prices absent the overcharge or maintained the higher price had the overcharge been discontinued. ${ }^{i 1}$

In short, in what the Supreme Court referred to as "the real economic world rather than an economist's hypothetical model," 72 it is inherently impossible to reconstruct with any reasonable certainty the subjective dynamics of a past pricing decision, much less determine what that decision would have been if a particular input had been less expensive. In his opinion Justice White recognized only one exception to this general rule-the case of preexisting cost-plus contracts and like arrangements where the impact of a single cost item on price can be determined with mathematical certainty without regard to market conditions and without inquiry into the mental processes of individual businessmen seeking to evaluate the subtle play of economic forces. ${ }^{73}$

Some two years later, the same "insuperable" evidentiary obstacles which had led Justice White to reject a claim of pass-on by way of defense were relied on by Judge Lord in dismissing the claims of an alleged homeowner class in the Plumbing Fixtures litigation. ${ }^{74}$ The defendant manufacturers in that case were charged with price-fixing on tubs, toilets, sinks, and similar items. In order to recover, however, a member of the homeowner class would have had to prove: (1) that, because of the conspiracy, the plumbing fixtures ultimately installed in his house had been sold by a defendant to a wholesaler at a price that included an overcharge; (2) that the wholesaler had passed on part of the overcharge by selling the fixtures to a plumbing contractor at an inflated price; (3) that some of the overcharge was

71. Id. at 493.

72. Id.

73. [T] here might be situations-for instance, when an overcharged buyer has a pre-existing "cost plus" contract, thus making it easy to prove that he has not been damaged-where the considerations requiring that the passing-on defense not be permitted in this case would not be present.

Id. at 494 .

74. Philadelphia Hous. Auth. v. American Radiator \& Standard Sanitary Corp., 50

F.R.D. 13 (E.D. Pa. 1970), aff'd sub nom. Mangano v. American Radiator \& Standard Sanitary Corp., 438 F.2d 1187 (3d Cir. 1971). This case was followed in Philadelphia Hous. Auth. v. American Radiator \& Standard Sanitary Corp., 323 F. Supp. 381 (E.D. Pa. 1970) (dismissing claims of public bodies which had purchased plumbing fixtures from intervening sellers). 
again passed on in the bid for the combined package of labor and materials that the plumbing contractor submitted to the builder; and (4) that the price at which the builder sold the class member his home also contained an overcharge. Those homeowner claimants that had bought used rather than new homes would in addition have had to show that each time their houses changed hands the purchase price was inflated by some part of the amount by which the defendantmanufacturer had originally overcharged the wholesaler for the plumbing fixtures. ${ }^{75}$

A number of factors combined to make it apparent that the homeowners in the Plumbing Fixtures case could not possibly have proven their claims. For one thing, unlike the situation in Hanover Shoe, they would have had to prove not one, but a series of pass-ons. For another, the plumbing fixtures which were actually involved in the alleged conspiracy were a very small part of the cost of the homeowners' houses. ${ }^{76}$

What is particularly significant about these considerations is that, far from being unique to Plumbing Fixtures, they apply equally to the gas vent pipe, concrete block, plastic pipe fittings, wall board, zipper slider, paper label, and other alleged conspiracies charged in many recent government suits involving substantially similar chains of distribution, and, of course, a fortiori to the cases involving equipment and raw materials even more distantly removed from the level at which consumers purchase. ${ }^{77}$ Virtually all of the courts that have

75. 50 F.R.D. at 25-26. As Judge John W. Lord found:

Each of these steps [represented] activity in a completely new and unrestrained market. ... It would be incredible if the price of a house were determined not by the shifts in supply [and] demand in the market for homes as a whole but rather by a relatively minuscule change (with respect to the selling price of the house) in the price of the plumbing fixtures. If the Supreme Court regarded the figures underlying corresponding assumptions as "virtually unascertainable" and applied such adjectives as "insuperable" and "insurmountable" to any attempt to support them in that case, it certainly follows $a$ fortiori that insuperable difficultics inhere in the premises underlying the claims at issue in the instant case.

Id. at 26.

76. The maximum overcharge on the fixtures in a typical two-bathroom house was estimated by the court to be between $\$ 10$ and $\$ 20$, while the total prices for the homes that the class members purchased ranged from $\$ 20,000$ to $\$ 30,000$. The court was understandably reluctant to believe that, but for a $\$ 10$ overchange on plumbing fixtures at the manufacturer level, a builder or former owner would have sold a $\$ 30,000$ house for $\$ 29,000$. Id.

77. Chromite sand, for example, passes through one chain of distribution before it is acquired by steel companies and used to make molds for steel ingot. The steel then passes through another chain of distribution before it is acquired by companies (such as car manufacturers) who fabricate products that consumers purchase. The cars and other such consumer products all have their own chains of distribution. Hence, for a consumer to prove injury in sucl a case, he would have to prove pass-ons not merely through multiple levels in a distribution chain, but through inultiple chains of distribution. 
considered the matter agree that in such cases-which account for the overwhelming mass of price-fixing conspiracies as reflected in five years of government suits-consumers cannot possibly establish compensable claims. ${ }^{78}$

A more difficult problem is presented by those situations where consumers purchase the price-fixed item itself from an intervening seller. Although courts have found that the obstacles to proving passon discussed in Hanover Shoe likewise bar consumer suits against wholesalers of breadi9 and eggs, $^{\text {so }}$ the court in Boshes $v$. General Motors Corporation ${ }^{\mathrm{s1}}$ took the position that retail purchasers of automobiles might be able to prove injury resulting from price-fixing and monopolization at the manufacturer level because they bought the product in the same form as the defendant sold it and not (like the homeowners in Plumbing Fixtures) "as a small component or

78. Before the Supreme Court's decision in Hanover Shoe, a number of courts found the inherent obstacles to proving pass-on to be particularly clear where the price-fixed item was incorporated into or used to produce another product, rather than the item itself being resold. Several courts denied defenses based on alleged pass-ons. E.g., Ohio Valley Elec. Corp. v. General Elec. Co., 244 F. Supp. 914 (S.D.N.Y. 1965); Atlantic City Elec. Co. v. General Elec. Co., 226 F. Supp. 59, 68-69 (S.D.N.Y. 1964); Commonwealth Edison Co. v. Allis-Chalmers Mfg. Co., 225 F. Supp. 332 (N.D. Ill. 1963), aff'd, 335 F.2d 203 (7th Cir. 1964); Hanover Shoe, Inc. v. United Shoe Mach. Corp., 185 F. Supp. 826, 831 (M.D. Pa.) (Goodrich, J.), aff'd per curiam, 281 F.2d 481 (3d Cir.), cert. denied, 364 U.S. 901 (1960). In addition, persons who had purchased the end product were consistently held to be too remote from the antitrust violation to recover. See, e.g., Commonwealth Edison Co. v. Allis-Chalmers Mff. Co., 315 F.2d 564, 566-67 (7th Cir.), cert. denied, 375 U.S. 834 (1963) (denying intervention by Illinois as parens patriae on behalf of consumers); Philadelphia v. Westinghouse Elec. Corp., 1961 Trade Cas. If 70,143, at 78,557 (E.D. Pa. 1961), aff'd on other grounds sub nom. Philadelphia Elec. Co. v. Westinghouse Elec. Corp., 308 F.2d 856 (3d Cir. 1962), cert. denied, 372 U.S. 936 (1963) (denying intervention by public utility commission on behalf of consumers).

After Hanover Shoe, numerous courts have reached the same result. These courts have sometimes directly ruled against the claims of remote purchasers. E.g., Illinois v. Ampress Brick Co., 67 F.R.D. 461,468 (N.D. IIl. 1975) (denying "standing" to "ultimate consumers" who purchased price-fixed concrete block as a component part of finished buildings); In re Antibiotics Antitrust Actions, 333 F. Supp. 310, 312 (S.D.N.Y. 1971) (dismissing claims of persons who purchased allegedly price-fixed drugs as an ingredient in finished animal feed products). They have also refused to allow such claims in a class action context. E.g., Dorey Corp. v. E.I. duPont de Nemours \& Co., 1975-2 Trade Cas. $\Uparrow$ 60,576, at 67,528 (S.D.N.Y. 1975) (excluding from settlement class those who purchased products which merely included allegedly price-fixed dyestuffs as an ingredient); Bill Minielli Cement Contracting, Inc. v. Richter Concrete Corp., 62 F.R.D. 381, 389 (S.D. Ohio 1973) (excluding from class indirect purchasers of cement not "marketed in the same form it was sold by the alleged antitrust violators"); City and County of Denver v. American Oil Co., 53 F.R.D. 620 (D. Colo. 1971) (denying class which included indirect purchasers who acquired allegedly price-fixed asphalt as one item in the contractor's paving bid). Cf. Balmac, Inc. v. American Metal Prods. Corp., 1972 Trade Cas. If 74,235, at 93,062 (N.D. Cal. 1972).

79. Donson Stores, Inc. v. American Bakeries Co., 58 F.R.D. 481 (S.D.N.Y. 1973).

80. United Egg Producers v. Bauer Int'l Corp., 312 F. Supp. 319 (S.D.N.Y. 1970).

81. 59 F.R.D. 589 (N.D. Ill. 1973). 
derivative of something else."s

The problem with relying on this distinction is that it fails to deal with the basic rationale for Hanover Shoe-the inherent impossibility of reconstructing pricing decisions in intervening markets. ${ }^{\$ 3}$ The Boshes court noted that the "retail automobile business is notorious for its haggling," that "buyers 'shop around' to get the best price," and that "[p]rices vary even among identical automobiles sold by different dealers." 84 If, as the Supreme Court held, the difficulties of proving a pass-on are insuperable even where it can be shown that the first buyer "raised his price in response to, and in the amount of, the overcharge," $8 \overline{5}$ it would be at least equally unavailing to try to determine whether a particular dealer passed on or absorbed an overcharge on a particular automobile in the admittedly volatile and highly competitive retail automobile market. In short, so long as the consumer is insulated by a reasonably competitive intervening market, Hanover Shoe itself suggests that there is no basis for distinguishing cases involving goods ultimately purchased intact by consumers from those dealing with equipment or materials used to produce consumer goods. ${ }^{86}$

A number of courts and commentators, finding the disallowance of consumer claims to be an undesirable and overly harsh result,

82. Id. at 597 .

83. Significantly, in In re Western Liquid Asphalt Cascs, 487 F.2d 191, 198 n.6 (9th Cir. 1973), cert. denied, 415 U.S. 919 (1974), the court recognized and sought to deal with this rationale by distinguishing Philadelphia Hous. Auth. r. Amcrican Radiator \& Standard Sanitary Corp., 323 F. Supp. 381 (E.D. Pa. 1970), on the ground that "[t]he court there found that the product passed through several successive unrestrained markets, with independent pricing decisions at each different level." In the case before it, the court found no such insulating effect in light of evidence showing that the defendants controlled or were affiliated with many of their direct buyers. 487 F.2d at 195, 198 \& n.6, 199. (The court crroneously distinguished the other Plumbing Fixtures case dealing with the pass-on question, Philadelphia Hous. Auth. v. American Radiator \& Standard Sanitary Corp., 50 F.R.D. 13 (E.D. Pa. 1970), aff'd sub nom. Mangano v. American Radiator \& Standard Sanitary Corp., 438 F.2d 1187 (3d Cir. 1971), as being of purely procedural import.)

84. 51 F.R.D. at 600 .

85. Hanover Shoe, Inc. $r$. United Shoe Mach. Corp., 392 U.S. 481, 493 (1968).

86. Judge Miles $W$. Lord, in In re Antibiotic Antitrust Actions, 333 F. Supp. 310 (S.D.N.Y. 1971), reasoned as follows:

[T] he facts suggest that the antibiotic product, once incorporated in the finished feed, passed through a second market composed of apparently competitive sellers, obscuring any effect the alleged antibiotic drug conspiracy might have had on the price of finished feed. The difficulty of plaintiff's case is greatly increased by the problems of competition, price determination, advertising and merchandising in the finished feed market, all of which enter into any determination of whether they felt the impact of the conspiracy.

Id. at 312. Undoubtedly, these considerations are as applicable to the ultimate purchaser who buys the originally price-fixed item as such after it has been resold, as they are to one who buys the item as a component of another product or scrvice. 
have criticized the application of the Hanover Shoe rule in the Plumbing Fixtures decision and like cases. ${ }^{87}$ The problem, however, is that none of these critics has adequately come to grips with the hard factual considerations upon which the rejection of allegations of pass-on has been based.

Judge Lord's decision has been said to represent an overly "literal" application in favor of defendants of a principle established by the Supreme Court for the benefit of plaintiffs. ${ }^{88}$ One recent opinion has even suggested that he should instead have interpreted Hanover Shoe in light of the "result orientation with which the Court has approached the whole area of private treble damage litigation." ${ }^{80}$ In other words, according to this school of thought, when Justice White referred to the difficulties of proving pass-on as "insuperable," he really meant that they were insuperable for defendants only, and that somehow a way would be found to allow plaintiffs faced with the identical evidentiary problems to prevail. ${ }^{90}$ Not only does this view manifest a cynicism which undermines confidence in the judicial process; it also fails to take into account the solid factual basis upon which Justice White's analysis rests. The Court's statements of the virtual impossibility of reconstructing the decisionmaking process by which Hanover priced its shoes were predicated upon specific observations about what the Court itself characterized as the "real economic world." 91 Those same factual conditions obviously would have had to apply to an effort by a consumer of shoes to disentangle precisely the same pricing decision by the shoe manufacturer (as well as subsequent pricing decisions by wholesalers and retailers) in seeking to establish a claim..$^{22}$

87. See, e.g., In re Master Key Antitrust Litigation, 1975-2 Trade Cas. If 60,648 (2d Cir. 1975), and 1973-2 Trade Cas. $\lceil 74,680$ at 94,978-80 (D. Conn. 1973); In re Western Liquid Asphalt Cases, 487 F.2d 191, 196-200 (9th Cir. 1973), cert. denied, 415 U.S. 919 (1974); Boshes v. General Motors Corp., 59 F.R.D. 589, 592-99 (N.D. Ill. 1973); Comment, Mangano and the Ultimate-Consumer Standing: The Misuse of the Hanover Doctrine, 72 Colum. L. Rev. 394 (1972).

88. In re Master Key Antitrust Litigation, 1975-2 Trade Cas. โf 60,648, at 67,824-25 n.11 (2d Cir. 1975).

89. In re Master Key Antitrust Litigation, 1973-2 Trade Cas. $\llbracket 74,680$, at 94,978 (D. Conn. 1973).

90. See generally In re Western Liquid Asphalt Cases, 487 F.2d 191, 196-200 (9th Cir. 1973), cert. denied, 415 U.S. 919 (1974); Carnivale Bag Co. v. Slide-Rite Mfg. Corp., 395 F. Supp. 287, 291 (S.D.N.Y. 1975).

91. 392 U.S. at 493 .

92. As stated by Judge Lord in Philadelphia Hous. Auth. v. American Radiator \& Standard Sanitary Corp., 50 F.R.D. 13, 29 (E.D. Pa. 1970), aff'd sub nom. Mangano v. American Radiator \& Standard Sanitary Corp., 438 F.2d 1187 (3d Cir. 1971):

[T] The Court [in Hanover Shoe] laid extremely heavy stress on the doubtfulness of the cconomic connection between the overcharge and the level of the price charged by Hanover Shoe, Inc. to its customers as well as the difficulties of proof of such a 
The courts which have refused to apply Hanover Shoe to bar consumer claims generally treat the entire issue as a question of standing. ${ }^{93}$ They accordingly reject the Plumbing Fixtures decision as an erroneous attempt to insert a requirement of privity into the law of standing, pointing out (correctly) that such a rule would be inconsistent with at least the target area test of standing adopted by some circuits. ${ }^{94}$ However, the disallowance of the homeowner's claims in Plumbing Fixtures had nothing more to do with standing than did

connection. These considerations are present of course regardless of whether more remote purchasers are plaintiffs or not.

93. See, e.g., In re Master Key Antitrust Litigation, 1975-2 Trade Cas. If 60,648, at 67,824-25 \& n.11 (2d Cir. 1975), and 1973-2 Trade Cas. T 74,680 (D. Conn. 1973); In re Western Liquid Asphalt Cases, 487 F.2d 191, 196-200 (9th Cir. 1973), cert. denied, 415 U.S. 919 (1974); Carnivale Bag Co. v. Slide-Rite Mfg. Corp., 395 F. Supp. 287, 289-90 (S.D.N.Y. 1975); Boshes v. General Motors Corp., 59 F.R.D. 589, 592-99 (N.D. Ill. 1973); Comment, supra note 87 , at 404-12.

The proponents of the House parens patriae bill, H.R. 8532, 94th Cong., 2d Sess. (1975), are apparently under the same misapprehension. The House Report states:

Some courts initially interpreted the Supreme Court's decision in Hanover Shoe, Inc. v. United Shoe Mach. Corp., 392 U.S. 481 (1968), to limit standing to sue to the first purchaser of a price fixed product. In Hanover Shoe the Court refused to allow a defendant to escape liability by asserting that his purchaser had passed on any illegal orercharge to the ultimate consumer. A major concern of the Court was to prevent the violator from [retaining] the ill-gotten gains of his illegal behavior. The Court noted that if the first purchaser was denied standing the ultimate con. sumers would have neither the incentive nor the ability to bring effective actions for return of the overcharges. 392 U.S. at 494 .

1975 REPORT, supra note 36, at 6 n.4 (cmphasis added). Thus, the House Report actually confuses the denial of the pass-on defense in Hanover Shoe with the totally unrelatcd issue of standing to sue.

94. The target area test articulated by the Ninth Circuit

focuses on whether the anticompetitive conduct directed against an area of the economy injured business operations conducted by the claimant in that sector of the economy. The resulting two-step approach requires identification of the affected area of the economy and then the ascertainment of whether the claimed injury occurred within that area.

In re Multidistrict Vehicle Air Pollution, 481 F.2d 122, 129 (9th Cir.), cert. denied, 414 U.S. 1045 (1973). See Twentieth Century Fox Film Corp. v. Goldwyn, 328 F.2d 190 (9th Cir.), cert. denied, 379 U.S. 880 (1964). The Second Circuit has followed and further articulated this "target area" test. Sec Long Island Lighting Co. v. Standard Oil Co., 521 F.2d 1269, 1274 (2d Cir. 1975), cert. denied, 96 S. Ct. 855 (1976); Calderone Enterprises Corp. v. United Artists Theatre Circuit, Inc., 454 F.2d 1292 (2d Cir. 1971), cert denied, 406 U.S. 930 (1972); Billy Baxter, Inc. v. Coca-Cola Co., 431 F.2d 183 (2d Cir. 1970), cert. denied, 401 U.S. 923 (1971). The result might be different under the alternative "direct injury" test, which

limits standing to the plaintiff whose immediate contractual or competitive relations with the violator are of such a nature as would insure that plaintiff has suffered direct harm. More remotely connected partics are excluded, and their injuries, if any, are described as remote, consequential or indirect.

Comment, supra note $\mathbf{8 7}$, at $\mathbf{3 9 7}$ (footnotes omitted). See, e.g., Nationwide Auto Appraiser Serv., Inc. v. Association of Cas. \& Sur. Cos., 382 F.2d 925 (10th Cir. 1967); Loeb v. Eastman Kodak Co., 183 F. 704 (3d Cir. 1910).

For a discussion of the different standards used by the courts on the isste of standing, see R. Sherman, Antitrust Standing: From Loeb to Malamud, $5 \mathrm{I}$ N.Y.U. L. REV. (June, 1976; forthcoming). 
the Supreme Court's refusal to recognize the pass-on defense in Hanover Shoe. ${ }^{95}$ Instead, both decisions were based upon a realistic assessment of the evidentiary problem involved and the unlikelihood that the pass-ons in question could ever be proven.

Such practical questions of the possibilitics and methods of proof are simply evaded in the cases which treat pass-on as an issue of standing. In the Master Key case, the Second Circuit suggested that the plaintiffs might be able to prove injury merely by establishing that there had been an overcharge and that they were consumers of the product in question, ${ }^{96}$ apparently not even considering the possibility that any overcharge might have been absorbed in its entirety by persons at intervening levels in the chain of distribution. In the IVestern Liquid Asphalt Cases, the court ducked the issue of how injury could be proven by relying on the lower court's assumption that some portion of the alleged overcharge had been passed on to the plaintiffs. ${ }^{97}$ In Carnivale Bag Co. v. Slide-Rite Mfg. Corp..${ }^{98}$ the

95. The defendants in Plumbing Fixtures did not even argue that the homeowner plaintiffs lacked standing. Such an argument would have been a strictly legal defense which could have been (and generally is) raised by a motion to dismiss based on the pleadings. See, e.g., Long Island Lighting Co. v. Standard Oil Co., 521 F.2d 1269 (2d Cir. 1975), cert. denied, 96 S. Ct. 855 (1976); Calderone Enterprises Corp. v. United Artists Theatre Circuit, 454 F.2d 1292 (2d Cir. 1971), cert. denied, 406 U.S. 930 (1972). Instead, the defendants sought to establish through interrogatorics that, as a factual matter, the homeowners could not possibly prove injury. 50 F.R.D. at 15-19. When the plaintiffs failed to respond with meaningful answers, the court imposed the sanction of assuming the relevant facts in the defendants' favor and ruled accordingly. Id. at 19. Similarly, in Balmac, Inc. v. American Metal Prods. Corp., 1972 Trade Cas. f 74,235 (N.D. Cal. 1972), in oral argument on the proposed certification of classes, counsel for defendant WallaceMurray Corp. explicitly stated with respect to the pass-on issue:

I don't think [the application of Hanover Shoe] is a threshold question as such, because this is not a standing question. This is the difference between standing and proof of injury based upon facts.

....

It depends on whether you look at the facts or the pleadings.

There is no issue that they have not stated a cause of action in their pleadings. However, this case is beyond the pleadings stage and therefore the question is whether their interrogatory answers raise such doubts that they have a claim that they should not be representative.

Transcript of Oral Argument, at 7-8, Mar. 2, 1972 (emphasis added).

96. In re Master Key Antitrust Litigation, 1975-2 Trade Cas. If 60,648, at 67,824 n.11 (2d Cir. 1975):

If the appellees establish at the trial for liability that the defendants engaged in an unlawful national conspiracy which had the effect of stabilizing prices above competitive levels, and further establish that the appellees were consumers of that product, we would think that the jury could reasonably conclude that appellants' conduct caused injury to each appellee.

97. In re Western Liquid Asphalt Cases, 487 F.2d 191, 196 (9th Cir. 1973), cert. denied, 415 U.S. 919 (1974). The Ninth Circuit used this assumption to distinguish Hanover Shoe. It noted that the Supreme Court

left open for future decision cases in which the passing on of the illegal overcharge might be more readily demonstrable. Ours is such a case. Based on affidavits, the 
court merely ruled that the issue of whether the plaintiffs could prove their claims was irrelevant to the defendants' motion to dismiss, which was denied on the ground that the plaintiffs were in the "target area" of the alleged violation and therefore had standing. ${ }^{99}$

While the question of whether pass-on can ever be proven in any of these cases thus lies in abeyance, the affidavits referred to in some of the opinions suggest that the Supreme Court's prognosis of the futility of such an effort is likely to be borne out. In the Master Key litigation, for example, Judge Blumenfeld based his denial of the defendants' motion for summary judgment in part on an affidavit of the plaintiffs' economist stating that the builders' hardware involved in that case was sold in a market characterized by inelastic demand. ${ }^{100}$

district court assumed that appellants could so show.

$I d$. at 196 (footnote omitted). The court of appeals then cited in a footnote the district court's statement that "plaintiffs ... can in some instances prove that the increased cost ... was in fact borne by the plaintiffs," " and continued:

The Supreme Court spoke of "virtually unascertainable figures" associated with proof that a particular intermediary "could not or would not have raised his prices absent the overcharge or maintained the higher price had the overcharge been discontinued." This was in relation to the liability issue, which in our case is obviated by the district court's assumption that appellants could prove an illegal overcharge which was passed on to them.

Id. at 196-97 n.5 (emphasis in original, citations omitted).

In addition, the Ninth Circuit distinguished the facts before it from those involved in Plumbing Fixtures by pointing out that the asphalt manufacturers controlled through stock ownership and other means many of the contractors who made up the intervening level in the distribution chain. The facts in Liquid Asphalt were similar in this respect to those in Perkins v. Standard Oil Co., 395 U.S. 642 (1969), upon which the Ninth Circuit relied. 487 F.2d at 197, 199. Perkins was a suit under the Robinson-Patman Act, 15 U.S.C. $\$ 13(a)(1970)$, in which Standard Oil was charged with giving discriminatorily low prices not only to certain direct competitors of the plaintiff retailer, but also to a wholesaler, which resold to the wholesaler's $60 \%$-owned subsidiary, which again resold to its 55\%-owned subsidiary (Regal Stations). Regal was another direct competitor of the plaintiff. The Supreme Court characterized the passage of the product in question "in this particular distribution chain" of interconnecting affiliates as a "formal exchange" which did not affect the plaintiff's right to recover. 395 U.S. at 648. As pointed out in 16C J. von Kalinowski, Business Organizations: Antitrust Laws and Trade Regulation $\$ 31.03$ [4], at 31-123 (1975), Perkins is distinguishable from "the majority of RobinsonPatman cases" where

wholly independent companies will stand betwcen the supplier and the ultimate retailer. In those situations, causation is more difficult to prove, since there is a much stronger possibility that intervening economic factors other than the discriminatory prices may have caused the competitive injury.

Western Liquid Asphalt is, of course, similarly distinguishable from the majority of price-fixing cases where intervening levels in the distribution chain are not controlled by defendants.

98. 395 F. Supp. 287 (S.D.N.Y. 1975).

99. Id. at 291, 293-94 (" $[W]$ hether plaintiffs can or cannot prove their case at trial is not dispositive of a motion to dismiss. . ..")

100. The affidarit of Willard F. Mueller, as quoted by the court, asserted that

"because finished hardware components are essential parts of a building and represent a relatively small part of the total cost of a building, the demand for these components is very inelastic, i.e., the volume of purchases [is] not affected by price." 
The court's opinion quotes with approval the economist's conclusion that " " $[w]$ hen demand is very inelastic, increases in costs due to an overcharge will be passed on in full." "101 Ironically, this is precisely the argument raised and rejected in Hanover Shoe. There, the defendant maintained that there could be no injury

where [an] overcharge is imposed equally on all of a buyer's competitors and where the demand for the buyer's product is so inelastic that the buyer and his competitors could all increase their prices by the amount of the cost increase without suffering a consequent decline in sales. ${ }^{102}$

Indeed, it was in response to this very claim that the Court made its much quoted statements about the "insuperable difficulty" of recreating pricing decisions "in the real economic world rather than an economist's hypothetical model." 103

While one may sympathize with the reluctance of some courts to disallow consumer claims, rulings which postpone decisions on the pass-on issue confer no benefit on consumers if those rulings merely afford consumers an opportunity to demonstrate in agonizing detail the futility of attempting to meet their burden of proof. If Justice White in Hanover and Judge Lord in Plumbing Fixtures were correct in their perception of the "real economic world"-and thus far no court or commentator has demonstrated the contrary-then it must be accepted as a fact of economic life that any injury to consumers resulting from the vast majority of price-fixing conspiracies which occur at levels other than retail is inherently incapable of being proven. ${ }^{104}$ Consequently, the proposed parens patriae bills now before

In re Master Key Antitrust Litigation, 1973-2 Trade Cas. II 74,680, at 94,981 (D. Conn. 1973), appeal dismissed, 1975-2 Trade Cas. \6 60,648 (2d Cir. 1975).

101. Id.

102. 392 U.S. at 492.

103. Id. at 493 .

104. This fact would in no way be altered by the proposed legislation. Indeed, the pending bills do not even purport to lower the existing legal standards with respect to proof of injury and damages. As Representative Rodino has stressed:

There is nothing in [the House] Bill that would change substantive antitrust law or the requirement that damages be proved under established legal standards. The State would not be able to collect a penny under the Bill's procedures unless it proves (1) that there was an antitrust violation, (2) that the violation caused injury to consumers, and (3) the amount of the resulting damages to consumers. The Bill would let consumers (through their State Attorney General) prove their damages collectively, but they would still have to prove actual damages.

Memorandum on H.R. 8532, The Parens Patriae Bill, from Representative Peter Rodino to House Rules Committee, at 3, Feb. 6, 1976 (on file with Yale Law Journal). Similarly, the House Report on H.R. 8532 stated:

[S]ubsection [4C(a)] creates no new substantive liability. ... Subsection 4C(a) thus 
Congress are likely to prove a cruel disappointment. The whole approach for protecting consumers which they embody is predicated on the erroneous assumption that consumers have viable treble damage claims in at least a significant body of antitrust suits. Since, as we have seen, this is not likely to be true even with respect to most price-fixing cases, the expectations raised by the parens patriae and class action innovations cannot possibly be realized.

This conclusion is in no way altered by the provision in the pending bills allowing

damages [to] be proved and assessed in the aggregate on the basis of statistical or sampling methods, or such other reasonable method of estimation as the court in its discretion may permit, without separately proving the fact or amount of individual injury or damage .....105

If the problems of proving pass-on are insuperable on an individual basis, it is difficult to imagine how such difficulties could be overcome by aggregation, or what statistical, sampling, or estimating methods would conceivably be relevant to such an endeavor. If there is more than one level of buyers and sellers in the chain of distribution, merely showing an overcharge by, for example, the manufacturers surely would be insufficient, since the possibility (indeed, the likelihood) that consumers were insulated to some degree from any overcharge by the operation of intervening markets would make it impossible to infer the extent to which either the class as a whole or any of its members was injured.

Similarly, a mere showing that prices increased at the retail level or even at each of the other intervening levels of the chain of distribution would not be sufficient to prove pass-on. As the Hanover Court pointed out with respect to the stronger hypothetical case of an intervening buyer raising his price in response to and in the amount of an overcharge, a pass-on still could not be proven because of the "nearly insuperable difficulty" of demonstrating that the intervening seller would not have raised his prices in any event. ${ }^{103}$

provides an alternative means to make practically available Federal remcdies at law, previously denied, for the vindication of existing substantive claims. . . .

The establishment of an alternative remedy does not increase any defendant's liability.

1975 RePORT, supra note 36, at 9. See 122 Cong. Rrc. H2065 (daily ed. Mar. 18, 1976) (Rep. Seiberling).

105. S.1284, 94th Cong., 1st Sess. $\S 401(4 \mathrm{C})(\mathrm{c})(1)$ (1975). H.R. 8532, 94th Cong., 2d Sess. $\S 2(4 \mathrm{D})(1975)$, is identical except that it also provides that "damages may be proved and assessed in the aggregate . . by the computation of illegal overcharges." Id.

106. 392 U.S. at 493 . 
Obviously, expanding the same proof to cover the "aggregate" injury of an entire class would not serve to cure the defect Justice White perceived. Indeed, it was just such an attempted classwide showing of pass-on, based on economists' arguments and statistics, that the Supreme Court rejected in Hanover Shoe itself.

\section{The Multiple Recovery Problem}

There appears to be a consensus among all courts that have considered the matter that the problems of proving pass-on must be handled in such a way as to avoid duplicative recoveries for the same alleged overcharge. ${ }^{107}$ If, for example, the plaintiff manufacturer in Hanover Shoe is permitted to recover three times the overcharges it paid, without any reduction for subsequent pass-on, then a different rule cannot be invoked to allow all of the wholesalers, retailers, and consumers who purchased Hanover's shoes to recover likewise for three times the same overcharges. To expose a defendant to multiple recoveries in such circumstances would subject it to, not three-fold, but six-fold or more damages for a single violation. In fact, the penalty would vary with the length of the chain of distribution (each new level adding another treble damage exposure), rather than the gravity of the offense, thus creating a singularly arbitrary mechanism for punishing or deterring violators. Such multiple recoveries cannot be justified in terms of compensation since, by hypothesis, permitting all of the claimants to recover will allow some if not most to enjoy full or partial windfalls. ${ }^{10 s}$

Accordingly, even those courts and commentators that treat pass-on as a question of standing recognize that something must be done either to avoid or to solve the multiple recovery problem. In the Master Key litigation, for example, Judge Blumenfeld took the position that the possibility of double liability might be obviated by

107. Sce In re Western Liquid Asphalt Cases, 487 F.2d 191, 198-200 (9th Cir. 1973), cert. denied, 415 U.S. 919 (1974); Carnivale Bag Co. v. Slide-Rite Mfg. Corp., 395 F. Supp. 287, 291-92 (S.D.N.Y. 1975); Boshes v. General Motors Corp., 59 F.R.D. 589, 596-97 (N.D. Ill. 1973); In re Master Key Antitrust Litigation, 1973-2 Trade Cas. I 74,680, at 97,979-80 (D. Conn. 1973), appeal dismissed, 1975-2 Trade Cas. If 60,648, at 67,825 n.11 (2d Cir. 1975).

108. The Supreme Court discussed the evils of multiple recoveries in Hawaii v. Standard Oil Co., 405 U.S. 251, 261-62 (1972). For additional cases relying on the danger of multiple recoveries as a reason for denying the claims of indirect purchasers, see Donson Stores, Inc. v. American Bakeries Co., 58 F.R.D. 481, 484 (S.D.N.Y. 1973); Balmac, Inc. v. American Metal Prods. Corp., 1972 Trade Cas. $\llbracket 74,235$, at 93,062 (N.D. Cal. 1972); City \& County of Denver v. American Oil Co., 53 F.R.D. 620, 631 (D. Colo. 1971); Philadelphia Hous. Auth. v. American Radiator \& Standard Sanitary Corp., 50 F.R.D. 13, 30 (E.D. Pa. 1970), aff'd sub nom. Mangano v. American Radiator \& Standard Sanitary Corp., 438 F.2d 1187 (3d Cir. 1971). 
the doctrine of collateral estoppel. ${ }^{100}$ Under this theory, if an indirect purchaser (such as a consumer) established a claim by proving an unbroken series of pass-ons, the judgment in that case could be asserted by the defendant against all subsequent claimants higher up in the chain of distribution as conclusively establishing that they had passed on any overcharge and therefore suffered no injury. ${ }^{110}$ In fact, this notion has no support in the law of collateral estoppel. Findings of fact in one action may be used under certain circumstances in a subsequent larwsuit only against a party to the first action who had a full and fair opportunity to litigate the factual issues in question. ${ }^{111}$ Therefore, persons higher in the chain of distribution would not be bound by a prior ruling in another case that they had passed on an overcharge; indeed, they no doubt could successfully contest any such assertion by defendants by relying on the controlling authority of Hanover Shoe.

Another device used by some courts to avoid dealing with the problem of multiple recoveries is to rely on the statute of limitations in situations where conflicting claimants are either already barred or, the court hopes, soon will be barred by their failure to file claims. ${ }^{12}$ While the court facing the latter situation may ignore the

109. In ve Master Key Antitrust Litigation, 1973-2 Trade Cas. $\int 74,680$, at 94,979 (D. Conn. 1973). Judge Blumenfeld relied on dictum in Boshes v. General Motors Corp., 59 F.R.D. 589, 596 (N.D. Ill. 1973) ("II]f the statute of limitations [did] not obviate the possibility of double liability, the doctrine of collateral estoppel probably would.")

110. Boshes v. Gencral Motors Corp., 59 F.R.D. 589, 596 n.9 (N.D. Ill. 1973).

111. The court in Boshes v. General Motors Corp., 59 F.R.D. 589,596 n.9 (N.D. III. 1973), cited Blonder-Tongue Laboratories, Inc. v. University of Ill. Foundation, 402 U.S. 313 (1971), for the proposition that collateral estoppel could be used to prevent multiple recoveries. But Blonder-Tongue reaffirmed the established rule that collateral estoppel cannot be asserted against a person not a party to the prior action:

Some litigants-those who never appeared in a prior action-may not be collaterally estopped without litigating the issue. They have never had a chance to present their evidence and arguments on the claim. Due process prohibits estopping them despite one or more existing adjudications of the identical issue which stand squarely against their position.

Id. at 329. See 1B Moore's Federal Practice Iff 0.441-.443 (2d ed. 1975).

In Carnivale Bag Co. v. Slide-Rite Mfg. Corp., 395 F. Supp. 287, 292 n.8 (S.D.N.Y. 1975), Judge Carter noted that the district courts in Boshes and Master Key were wrong in their suggested application of collateral estoppel.

112. See, e.g., Carnivale Bag Co. v. Slide-Rite Mfg. Corp., 395 F. Supp. 287, 292 (S.D.N.Y. 1975) ("[T]he four-year statute of limitations, 15 U.S.C. \$15b, may limit the extent of defendants' liability to some slider purchasers and bar the claims of others altogether."); In re Master Key Antitrust Litigation, 1973-2 Trade Cas. If 74,680, at 94,979 (D. Conn. 1973) ("[T]he statute of limitations may limit the extent of liability to some plaintiffs."); Boshes v. Gencral Motors Corp., 59 F.R.D. 589, 596 (N.D. III. 1972) ("[T] he statute of limitations has already cut off the rights of the retail dealers from whom the plaintiffs presently before the court purchased their automobiles.")

Howerer; the issuc of whether or not conflicting claims have actually been filed has little bearing on determining how much of an alleged overcharge, if any, was passed on to consumers. Obviously, the claim of a consumer who in fact was not injured cannot 
issue for the time being, the assertion of conflicting claims must always be regarded as a real possibility until the statute has actually run, since it is hardly unusual for class actions on behalf of large numbers of new claimants to be filed just before the running of the statute. ${ }^{113}$ Furthermore, in most cases-particularly where large amounts of money are at stake-conflicting claims are asserted as a matter of course either in the same lawsuit or in separate actions consolidated for pre-trial proceedings, and the courts therefore must deal directly with the problems of preventing multiple recoveries. ${ }^{114}$

Significantly, those courts which have declined to follow Hanover Shoe and Plumbing Fixtures and have instead assumed that pass-on is susceptible to proof, have also concluded that each overcharge must be divided up on an individual basis in accordance with what the interests of the conflicting claimants are actually proven to be. In the Western Liquid Asphalt Cases, for example, the Ninth Circuit ruled that damages had to be apportioned among the claimants at various levels in the chain, with intermediaries (such as contractors) recovering for those portions of an overcharge they in fact absorbed and with the ultimate consumers (public entities which had contracted for the repair or construction of roads) recovering for only that portion of the overcharge actually passed on through all prior levels. ${ }^{115}$

be enhanced by the failure of the person who did absorb the overcharge to bring suit himself. Thus, even if all persons in the chain are not before the court as litigants, many of them still will have to be brought into the discovery process and perhaps even the trial to determine whether there was a pass-on to consumer claimants.

113. E.g., City of New York v. International Pipe \& Ceramics Corp., 44 F.R.D. 584, 586 (S.D.N.Y. 1968), rev'd, 410 F.2d 295 (2d Cir. 1969) (class action filed one day before running of statute of limitations); Philadelphia Elec. Co. v. Anaconda Am. Brass Co., 42 F.R.D. 324, 326 (E.D. Pa. 1967) (class actions filed within a weck or two of the cxpiration of the limitations period).

114. E.g., Philadelphia Hous. Auth. v. American Radiator \& Standard Sanitary Corp., 309 F. Supp. 1057, 1062-63 (E.D. Pa. 1969), aff'd sub nom. Mangano v. American Radiator \& Standard Sanitary Corp., 438 F.2d 1187, 1188 (3d Cir. 1971) (class actions brought on behalf of wholesalèrs, sub-contractors, general contractors, owner-builders, and various categories of end users); West Virginia v. Chas. Pfizer \& Co., 314 F. Supp. 710 (S.D.N.Y.), aff'd, 440 F.2d 1079 (2d Cir. 1970), cert. denied, 404 U.S. 871 (1971) (class actions brought by wholesale druggists, retail drug stores, private hospitals, and states on behalf of themselves and other consumers within their borders); Donson Stores, Inc. v. American Bakeries Co., 58 F.R.D. 481 (S.D.N.Y. 1973) (class actions brought by both retailers and consumers).

Section 1407(a) of the United States Code, Title 28 (Supp. IV 1974), authorizes the transfer of civil actions involving common questions of fact to any one district "for coordinated or consolidated pretrial proceedings." As screral courts have noted, interpleader provides another means for ensuring that all competing claims are before the court. See 28 U.S.C. $\$ 1335$ (1970); cases cited in note 112 supra.

115. Problems of the apportionment of damages, as between an intermediary and an ultimate consumer, may be treated after liability is established, unless it be clear that no ultimate consumer was damaged. If an intermediary is shown to have been damaged by payment of an illegal overcharge which was not passed on to ultimate 
Western Liquid Asphalt did not involve any class actions. In City and County of Denver v. American Oil Company, ${ }^{110}$ however, the court considered the same problem of allocating overcharges in the context of even a small alleged class of 126 public entities, and recoiled at the prospect. It noted that in order to trace an overcharge even on a simple paving job, the cost of the asphalt would have to be broken out of the bid and an inquiry made as to the precise extent, if any, to which that cost influenced the price charged for the paving contract as a whole. ${ }^{117}$ The court observed that, while the calculation for the paving contract would not be simple, it would be "child's play" as compared to "tracing the cost of asphalt into the cost of a 10-mile stretch of new highway blasted out of the Colorado mountains."118 Describing the ways in which proof of pass-on and injury would vary from claimant to claimant, the court concluded that " $[t]$ o try this case as a class action might be an accountant's paradise, but it would be a court's purgatory." 119

Not unsurprisingly, in the Boshes case, where the alleged class consisted of 30 to 40 million persons ${ }^{120}$ instead of a mere 126 , Judge Decker came to the same conclusion that the need to determine in each instance whether an individual retailer had absorbed or passed on a putative overcharge rendered the lawsuit hopelessly unmanageable as a class action. ${ }^{121}$

consumers, appellees' liability to ultimate consumers, to that extent, may be decreased.

... [i]n passing-on cases, the intermediary should recover the amount of the overcharge that was not passed on, if the proof shows that the ultimate consumers did not pay it all, and any lost profits resulting from increased costs. The ultimate purchasers should obtain the remainder of the overcharge, and any other damages proximately caused. ...

....

... As we have said, the amount of the overcharge is not subject to double payment, because appellees' liability in that regard is to be apportioned after the amount of the overcharge is fixed. Further, each plaintiff (including appellants), be he intermediary or ultimate consumer, will be awarded only such further damages, including lost profits, as he may reasonably prove allocable to him.

487 F.2d at 200-01.

116. 53 F.R.D. 620 (D. Colo, 1971).

117. Id. at 636-37.

118. Id.

119. Id. at 637 .

120. Boshes v. General Motors Corp., 59 F.R.D. 589, 599 (N.D. Ill. 1973).

121. While this court disagreed with defendant that proof of damage on an individual basis was not sufficient to defeat plaintiffs' standing to sue, that determination should not be confused with the question of whether individual questions of damages are so numerous and complex among class members that the class is unmanageable....

... [S]everal important factors might either mitigate or eliminate a damage claim of any indiridual plaintiff. For example, even if monopolization and pricefixing 
The parens patriae bills presently before Congress are calculated to increase dramatically the number of conflicting claims with which the courts will have to deal, since the bills would invite the states to assert consumer claims in virtually all large antitrust litigations. For example, while only purchasers of zippers have thus far sued in the zipper slider case, ${ }^{122}$ if the proposed legislation becomes law the states would presumably feel obligated to protect the "natural persons" residing within their borders who purchased zippers as part of clothing. In those cases where only the owners of apartment houses have thus far asserted claims in competition with wholesalers, subcontractors, and general contractors on account of allegedly pricefixed items (such as plumbing fixtures) included in such structures, ${ }^{123}$ the states may well consider it their duty to try to vindicate the competing claims of tenants.

The problem, however, is that unlike the present class action rule, the proposed parens patriae procedures would not allow courts the escape mechanism of declaring the suit unmanageable. ${ }^{124}$ Hence, any court unlucky enough to be chosen as the forum for a state parens patriae action would have no option but to adjudicate the claims brought before it, however numerous and minuscule they might be. To determine what this would mean in practice, one might consider that, according to the House Committee Report, the new legislation is specifically intended to cover the kind of case in which it is claimed that 50 million consumers have each suffered $\$ 1$ in damages. ${ }^{125}$ Since a case of that magnitude is likely to arise only where the alleged violation is remote from consumers in the chain of distribution, the

resulting in "excess profits" for GM were proven plaintiffs would still have to prove that retail dealers passed on the "overcharge" to them. Although on an individual basis the foregoing would not be impossible, it would be an endless task on a class-wide basis.

59 F.R.D. at 600 (emphasis in original). For additional cases, see In re Master Key Antitrust Litigation, 1973-2 Trade Cas. ff 74,680 at 94,979 \& n.6 (S.D.N.Y. 1973) (court suggesting in dictum that the "insuperable problems of class action management" could result in pretrial dismissal of claims based on the inability to prove damages); Balmac, Inc. v. American Metal Prods. Corp., 1972 Trade Cas. If 74,235, at 93,063 (N.D. Cal. 1972) (the class actions would complicate the liability determinations).

122. Carnivale Bag Co. v. Slide-Rite Mfg. Corp., 395 F. Supp. 287 (S.D.N.Y. 1975).

123. F.g., In re Master Key Antitrust Litigation, 1973-2 Trade Cas. If 74,680 (D. Conn. 1973), appeal dismissed, 1975-2 Trade Cas. $\Upsilon_{60} 648$ (2d Cir. 1975) (certifying a class of building owners); Philadelphia Hous. Auth. v. American Radiator \& Standard Sanitary Corp., 50 F.R.D. 13 (E.D. Pa. 1970), aff'd sub nom. Mangano v. American Radiator \& Standard Sanitary Corp., 438 F.2d 1187 (3d Cir. 1971).

124. FED. R. Civ. P. 23(b)(3)(D) instructs a court, in determining whether "a class action is superior to other methods" of adjudicating the controversy, to consider "the difficultics likely to be encountered in the management of [the] class action." Neither the Senate nor the House bill contains a similar provision for parens palriae suits.

125. 1975 REPORT, supra note 36 , at 6 . 
court, unless it followed Plumbing Fixtures and dismissed the consumer claims en masse, would have to find some way to adjudicate the rights of 50 million consumers, not only as against the defendants, but also as against competing plaintiffs at other levels in the chain of distribution. These other plaintiffs, of course, are likely to claim that, to the extent there was any illegal overcharge, they, rather than the consumers, were the ones who absorbed it. The attempt to resolve the conflicts among the competing claims in such a case will consume lifetimes of judicial energy ${ }^{126}$ without any possibility of producing meaningful recoveries for the individual consumers.

The draftsmen of the proposed bills may hope that these problems can be obviated by provisions in the legislation for proof of injury to a class "in the aggregate" based on statistical or sampling methods or some other "reasonable system of estimating aggregate damages." 127 But in fact, as we have shown, the problems of proving even the existence of a pass-on do not become any easier simply by shifting the focus from the individual to the class; this is true a fortiori if one proceeds on the assumption that pass-ons can be proven, so that the problem becomes one of determining as a factual matter what portion of each overcharge was borne by each of the various claimants at the different levels in the distribution chain. Again, "sampling or statistical methods" cannot solve the problem. To take the circumstances of the Boshes case, convincing testimony by some percentage or even all of a group of retailers chosen as a sample that they absorbed all overcharges has no probative value with respect to some other retailer who may have sold a particular car at a higher price without absorbing any (or as much) of the overcharge. ${ }^{12 s}$

In sum, the proposed parens patriae bills would require the courts

126. As Judge Ely stated in In ve Hotel Tel. Charges, 500 F.2d 86, 89 (9th Cir. 1974):

The appellees' Sherman Act claims, while charging hundreds of hotels with similar conduct, nonetheless raise individual questions that could require decades of litigation. . . . In a class of forty million, assuming only ten percent of these unknown class members came forward with claims, and assuming the proof of each claim required only ten minutes, approximately one hundred years would yet be required to adjudicate the claims.

127. H.R. 8532, 94th Cong., 2d Sess. $\$ 4 D$ (1975); accord, S. 1284, 94th Cong., lst Sess. $\$ 401(4 \mathrm{C})(\mathrm{c})(\mathrm{l})(1975)$.

128. In Boshes v. General Motors Corp., 59 F.R.D. 589, 600 (N.D. IIl. 1973), Judge

Decker stated in holding that the suit could not bc maintained as a class action:

Competition among dealers in the same brand of automobile, in the same "pricerange" or "class" of automobile manufactured by other companies, and within the overall automobile market varies considerably from one locale to another. . . Prices vary even among identical automobiles sold by different dealers. Prices vary considerably among the various makes, for example, Cherrolet and Cadillac. Hence, there does not appear to be any way to rationally and fairly distribute any damage "fund", assuming a violation by GM could be proved. 
to deal with antitrust litigation on an unprecedented scale involving conflicts between competing claimants and possible duplication between different types of state parens patriae claims, all without any guidance as to how the multitude of ensuing problems are to be dealt with. Since these suits are likely to involve antitrust violations which actually resulted in no compensable harm to consumers at all or where, at best, consumers will be pitted in a costly struggle against other claimants that is likely to dissipate any meaningful recovery, one might well question-before the bills become law-whether the burdens to be thrust on the courts really have any social justification whatsoever and whether the kinds of lawsuits to be engendered are rationally calculated to serve the consumer interest.

\section{B. Other Types of Antitrust Violation}

Of the 346 civil and criminal actions commenced by the Department of Justice during the 1971-1975 period, 159 actions alleged violations other than price-fixing. ${ }^{129} \mathrm{~A}$ consideration of these cases demonstrates that the more dissimilar a violation is from the exaction of overcharges through price-fixing, the more difficult it becomes to prove that consumers have suffered any compensable injury at all, and consequently the more irrelevant parens patriae actions and fluid recoveries become to any real effort at protecting consumers. ${ }^{130}$

Five of the cases brought by the Government during the period

129. Of these 159 cases, nine involved charges of horizontal price-fixing as well and thus overlap with the 192 cases in the latter category.

In addition to the 192 horizontal price-fixing cases referred to above, four of the suits brought by the Government over the past five years have involved vertical resale price maintenance agreements. United States v. Toyota Motor Sales, U.S.A. Inc., 5 TrAde REG. REP. If 45,075 (Cas. No. 2443) (N.D. Cal. 1975) (disposition noted); United States v. Bird Corp., 5 Trade Reg. Rep. ff 45,072 (Cas. No. 2255) (E.D.N.Y. 1972) (disposition noted); United States v. Wayne Corp., 5 TRAde REg. REP. I 45,072 (Cas. No. 2239) (S.D. Ind. 1972) (disposition noted); United States v. Nissan Motors Corp. in U.S.A., 5 Trade REg. REP. 745,072 (Cas. No. 2266) (N.D. Cal., filed June 30, 1972) (disposition noted). Of these four cases, only the last involved allegations of the fixing of retail prices at which goods or services were sold to consumers. Furthermore, as a general matter, the economic impact of resale price maintenance on consumers is more problematic than that of horizontal price-fixing since, by their nature, vertical arrangements do not insulate price from normal interbrand competition.

130. Both bills are limited to parens patrine suits on behalf of persons injured by violations of the Sherman Act, 15 U.S.C. $\$ \S 1-2$ (Supp. IV 1974). H.R. 8532, 94th Cong., 2d Sess. $\$ 2(4 \mathrm{C})$ (1975); S. 1284, 94th Cong., 1st Sess. $\$ 401(4 \mathrm{C})$ (1975). While suits alleging illegal tie-ins and mergers commonly rely on $\$ \$ 3$ and 7 of the Clayton Act, 15 U.S.C. $\$ \$ 14,18(1970)$, these types of suits can also be brought under the Sherman Act. See, e.g., Fortner Enterprises, Inc. v. United States Steel Corp., 394 U.S. 495 (1969) (tie-ins); United States v. First Nat'l Bank \& Trust Co., 376 U.S. 655 (1964) (merger). Therefore, we include in our discussion Justice Department cases alleging these violations.

The "fluid recovery" provisions of the House bill are limited to cases involving willful price-fixing. H.R. 8532, 94th Cong., 2d Sess. $\$ 2(4 D)$ (1975). See note 169 infra. 
studied involved tie-ins ${ }^{131}$-the sale or licensing of one item on the condition that the purchaser also buy a second item. In each case, competitors foreclosed from selling the tied product clearly would have suffered compensable harm, but buyers could claim to be injured only if they were forced either to buy something they did not want or to pay more for the tied product than would have been the case without the tie. While this leaves open the possibility that consumers who are the direct targets of a tie-in might have viable treble damage claims, the record revealed by the government suits indicates that such tie-ins as actually occur in the economy are generally far removed from consumers in the chain of distribution. In one case, ${ }^{132}$ a defendant would only allow its grain elevator in a given port to be used if the shipping companies also used its stevedoring services in unloading their grain; in another case, ${ }^{133}$ several defendant copper companies were charged with licensing their patented plumbing system only to persons who agreed to build it with copper pipe. Clearly, it would be an insuperable task to show that the effects of such alleged violations actually penetrated through all of the intervening stages of the economy, causing individual consumers some quantifiable injury. ${ }^{134}$

Some 20 government suits during the past five years involved horizontal territorial divisions (including those resulting from restrictive licensing arrangements) and customer allocations. ${ }^{135}$ The likely effect of such violations on consumers varies from case to case. For example, in United States v. Topco Associates, Inc., the territorial division allowed the defendant grocery stores to sell their own brands

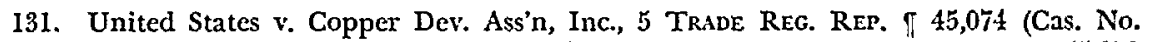
2379) (S.D.N.Y. 1975); United States v. Goodpasture, Inc., 5 Trade REg. REP. I 45,073 (Cas. No. 2360) (S.D. Tex., filed Dec. 28, 1973); United States v. M \& T Chemicals, Inc., 5 Trade Reg. REP. If 45,072 (Cas. Nos. 2207-2209) (S.D.N.Y., filed Jan. 26, 1972) (dispositions noted).

132. United States v. Goodpasture, Inc., 5 Trade Reg. ReP. I 45,073 (Cas. No. 2360) (S.D. Tex., filed Dec. 28, 1973).

133. United States v. Copper Dev. Ass'n, Inc., 5 Trude Rec. Rrr. $\$ 45,074$ (Cas. No. 2379) (S.D.N.Y. 1975).

134. The other three government suits also alleged tic-ins far removed from consumers in the chain of distribution. In these suits, the Justice Department claimed that the "defendant companies ha[d] tied the purchase of electroplating materials which [they] sell, to the sale of nickel to [their] customers." United States $\mathrm{V}$. M \& T Chemicals, Inc., 5 TrAdE REg. REP. If 45,072 (Cas. Nos. 2207-2209) (S.D.N.Y. 1975).

135. See 5 TRADE REG. ReP. Tff 45,073-75 (1976) (citations on file with Yale Law Journal). Another three cases alleged vertical agreements allocating markets; none appears to involve sales to individual consumers. United States v. Bally Mfg. Corp., 5 TrudE REg. REP. If 45,072 (Cas. No. 2260) (N.D. Ill. 1972) (disposition noted); United States v. Safety First Prods, Corp., 5 Trade Reg. ReP. đ 45,072 (Cas. No. 2245) (S.D.N.Y. 1972) (disposition noted); United States v. Webster Elec. Co., 5 Trade Reg. Rer. If 45,071 (Cas. No. 2161) (E.D. Wis. 1971) (disposition noted). 
in competition with those of the large supermarket chains, and thus probably increased competition at the consumer level. ${ }^{136}$ Horizontal market allocation schemes may generally reduce competition, but in many cases the injury is very difficult to measure in terms of money damages. The problem of proving a compensable injury to consumers is aggravated by the fact that most of the cases brought by the Government in this area involve companies at the production level (for example, producers of lithium ${ }^{137}$ and publishers of books ${ }^{138}$ ), so that once again consumers are insulated from the effects of the violation by persons at several intervening steps in the chain of distribution, each of whom presumably bought and sold in a reasonably competitive market. While it is theoretically possible that a market division conspiracy directly affecting consumers might be shown to produce ascertainable overcharges, few of the cases brought by the Justice Department during the past five years appear to fit in this category. ${ }^{139}$

Another 22 government civil and criminal actions charged various defendants with monopolization, attempted monopolization, and conspiracies to monopolize ${ }^{1 \neq 0}$ under $\S 2$ of the Sherman Act. ${ }^{1+1}$ Some $\S 2$ violations-such as the monopolization of automobiles charged in Boshes-might be shown to have resulted in overcharges to consumers, but for the insulation of intervening levels in the distribution chain. But in most of the government actions the likelihood of showing any overcharge was further reduced by the nature of the alleged violation

136. 405 U.S. 596,610 (1972):

The District Court determined that by limiting the freedom of its individual members to compete with each other, Topco was doing a greater good for fostering competition between members and other large supermarket chains.

The Court declined to consider this factor, holding that horizontal agreements to divide territorial markets are illegal per se. See id. at 611-12.

137. United States v. Foote Mineral Co., 5 Trade Reg. Rep. If 45,074 (Cas. No. 2396) (E.D. Pa., filed June 28, 1974) (disposition noted).

138. United States v. Addison-Wesley Publishing Co., 5 Trade Reg. Rer. If 45,074 (Cas. No. 2419) (S.D.N.Y., filed Nov. 25, 1974). For additional cases, see United States v. Tom's Foods Ltd., 5 Trude Reg. Rer. If 45,075 (Cas. No. 2449) (MI.D. Ga. 1975) (customer allocation conspiracy by manufacturers of snack foods); United States v. DeBecrs Indus. Diamond Div. Ltd., 5 TrAde Reg. REP. If 45,074 (Cas. Nos. 2425, 2426) (S.D.N.Y. 1975) (market allocation and price-fixing conspiracy by producers of diamond grit); United States v. Climatrol Corp., 5 Trdde Reg. Rer. If 45,074 (Cas. Nos. 2376, 2377) (S.D. Fla. 1975) (conspiracy among building material firms to allocate sales of screen enclosures); United States v. Amateur Softball Ass'n, 5 Trade Reg. Rep. ff 45,073 (Cas. No. 2359) (W.D. Okla. 1974) (conspiracy by sporting goods manufacturers and softball association to limit number of manufacturers licensed to use association's tradcmark).

139. Of the 20 suits alleging market division conspiracies, only five involved the division of retail markets. The use of parens palriae in this small group of cases is' subject to the same problems outlined in Part III below in the discussion of retail pricefixing.

140. See 5 Trade Reg. Rrp. If 45,071-75 (1976) (citations on file with Yale Law Journal).

141. 15 U.S.C. $§ 2$ (Supp. IV 1974). 
itself. In several of these cases (such as those involving monopolization of mobile home transportation ${ }^{142}$ and airline routes ${ }^{1 \pm 3}$ ), the alleged wrongdoing related to proceedings before an administrative agency which was empowered to grant certificates of convenience and necessity and regulate rates, and which quite possibly protected consumers from any overcharges resulting from the alleged violations. When the major networks were charged with monopolizing prime time TV entertainment programs, ${ }^{14 *}$ there was again no possible relationship between the alleged violation and any identifiable out-of-pocket loss to consumers. Indeed, in many instances (for example, the Justice Department's suits alleging monopolization of electronic components, ${ }^{145}$ replacement tires, ${ }^{146}$ milk, ${ }^{147}$ and wholesale books and magazines ${ }^{145}$ ) an important means by which the defendant supposedly monopolized was through predatory pricing and the offering of free additional benefits to customers ${ }^{149}$-all of which should have had a beneficial rather than an adverse impact on consumers in the short run, however harmful the resulting impairment to competition might have eventually proven to have been over the long run.

Another major category of government antitrust actions consists of alleged violations related primarily to the defendants' purchasing function. Twenty such suits have been brought, inter alia, against various lumber companies charged with conspiracy to eliminate competition among themselves in the purchase of public timber, ${ }^{150}$ against

142. United States v. Morgan Drive Away, Inc., 5 Trade Reg. Rep. I 45,074 (Cas. Nos. 2330, 2421) (D.D.C., indictment returned Aug. 2, 1973, civil complaint filed Dec. 5, 1974) (dispositions noted).

143. United States v. Braniff Airways, Inc., 5 Trade Reg. Rep. đ 45,075 (Cas. No. 2432) (S.D. Tex., indictment returned Feb. 14, 1975).

144. United States v. CBS, Inc., 5 TRADE Reg. ReP. If 45,074 (Cas. Nos. 2422-2424) (C.D. Cal., filed Dec. 10, 1974); United States v. National Broadcasting Co., Inc, 5 Trade REc. ReP. I 45,072 (Cas. Nos. 2232-2234) (C.D. Cal., filed Apr. 14, 1972) (dispositions noted).

145. United States v. Industrial Electronic Eng'rs, Inc., 5 TRADE REG. REP. $\{45,073$ (Cas. No. 2329) (C.D. Cal., filed June 27, 1973).

146. United States v. Goodyear Tire \& Rubber Co., 5 Trade Reg. Rep. If 45,073 (Cas. Nos. 2335, 2336) (N.D. Ohio 1976).

147. United States v. Mid-American Dairymen, Inc., 5 Trade Reg. Rep. If 45,073 (Cas. No. 2358) (W.D. Mo., filed Dec. 27, 1973); United States r. Dairymen, Inc., 5 Trade Reg. REP. (f 45,073 (Cas. No. 2312) (W.D. Ky., filed Mar. 29, 1973); United States v. Associated Milk Producers, Inc., 5 Trade Reg. ReP. If 45,072 (Cas. No. 2219) (S.D. Tex. 1975).

148. United States v. Molasky, 5 Trade Reg. Rer. If 45,073 (Cas. No. 2345) (E.D. La. 1975).

149. E.g., United States v. Associated Milk Producers, Inc., 5 TrAde Rec. Rep. \45,072 at 53,461 (Cas. No. 2219) (S.D. Tex. 1975); United States v. Alid-America Dairymen, Inc., 5 Trade Reg. Rep. $\int 45,073$, at 53,556 (Cas. No. 2358) (W.D. Mo., filed Dec. 27, 1973); United States r. Industrial Electronic Engrs, Inc., 5 Trade REg. REP. If 45,073, at 53,535 (Cas. No. 2329) (C.D. Cal., filed June 27, 1973); United States v. Dairymen, Inc., 5 Trade Reg. Rep. $\llbracket 45,073$, at 53,522 (Cas. No. 2312) (W.D. Ky., filed Mar. 29, 1973).

150. United States v. Champion Int'l Corp., 5 Trade Reg. Rep. $\int 45,074$ (Cas. Nos. 2405, 2406) (D. Ore., indictment returned Sept. 6, 1974). 
firms charged with conspiracy to boycott a particular vendor, ${ }^{151}$ and against many different defendants, in a wide variety of industries, charged with unlawful reciprocity ${ }^{152}$ (using their purchasing power to gain an unfair advantage in the sale of their products by buying from those suppliers who reciprocate by purchasing from them). All of these practices distort competition to some degree and therefore arguably injure consumers in a general way; however, it is difficult to see how any of these violations would result in specific, quantifiable injury to consumers as opposed to the vendors and competitors who are often directly injured. Indeed, many of these practices tend to lower the costs which producers of consumer goods pay for raw materials, so that the effect on consumer prices, if any, would be downward rather than upward.

Finally, 57 government suits during the 1971-1975 period have dealt with mergers. ${ }^{153}$ Turning first to those involving horizontal mergers between actual competitors, there is considerable doubt as to which, if any, of these actual or proposed acquisitions did result, or (if not enjoined prior to consummation) would have resulted, in any harm whatsoever to consumers, compensable or otherwise. In many cases ${ }^{15 t}$ after United States v. Von's Grocery Co. ${ }^{1 \bar{v} \mathrm{~s}}$ and United States $v$. Pabst Brewing Co., ${ }^{150}$ mergers were attacked because they would have increased concentration in a given industry, even though the economic consequences of such increased concentration were at best speculative. ${ }^{157}$ Even where a clear violation of $\S 7$ of the Clayton Act can

151. United States v. Material Handling Institute, Inc., 5 Trade REg. REP. If 45,072 (Cas. No. 2270) (W.D. Pa. 1973).

152. See 5 TrAde REg. Rep. If 45,071-74 (1976) (citations on file with Yale Law Journal).

153. See 5 Trade REg. REP. fI 45,071-75 (1976) (citations on file with Yale Law Journal).

154. E.g., United States v. American Bldg. Maintenance Indus., 422 U.S. 271 (1975);

United States v. Leggett \& Platt, Inc., 5 Trade Reg. REP. $\llbracket 45,074$ (Cas. No. 2395) (W.D.

Mo., filed June 28, 1974); United States v. Trust Co., 5 Trade Reg. Rep. I 45,071 (Cas.

No. 2169) (N.D. Ga. 1971) (disposition noted).

155. 384 U.S. $270(1966)$.

I56. 384 U.S. 546 (1966).

157. There is a singular lack of consensus among economists as to whether industry concentration has any relation at all to profitability, which is often used as an indicator of the degree of competition prevailing in the industry. See, e.g., B. Bock, Concentration, Oligopoly, And Profit: Concepts vs. Data 32-36 (1972); Brozen, Concentration and Profits: Does Concentration Matter?, 19 ANTITRust BulL. 381, 388 (1974). The effect of concentration on price is even more problematical; indeed, several studies have indicated that over the past decade or more prices have actually risen less in concentrated than nonconcentrated industries. MfcLaren, Oligopoly and Inflation (III): The View From the Justice Department, 4 AntrTrust L. \& Econ. Rev., Spring, 1971, at 94, 99; Weiss, The Role of Concentration in Recent Inflationary Price Movements: A Statistical Analysis, 4 ANTitrusr L. \& Econ. REv., Spring, 1971, at 109; see Handler, stupra note 2, at 225-29, 267-72 (reporting research of Dr. Jerome Cohen). 
be made out, appraising the economic effects of a change in industry structure involves so many imponderables that there is no way to translate a tendency to lessen competition into a measurable effect on price, much less show a specific impact on individual consumers. The impossibility of showing compensable harm to consumers from a merger becomes even more obvious when we consider vertical acquisitions ${ }^{15 s}$ and, a fortiori, market extension mergers which involve at most the elimination of potential competition. ${ }^{158}$

In sum, in the vast majority of the Justice Department antitrust cases currently being brought, ${ }^{100}$ problems of pass-on or of the nature of the violation itself make it highly unlikely that consumers would be able to establish compensable claims. Consequently the treble damage action must be recognized as a generally inappropriate vehicle for protecting the consumer interest.

\section{Price-Fixing Cases Directly Affecting Consumers}

Only 45 of the 346 Justice Department suits have alleged conspiracies to fix the retail prices paid by consumers for goods or services. The largest single category of retail price-fixing charged by the Government has been in the area of fee schedules and codes of ethics adopted by various associations of professionals and realtors. No less

158. As recently noted by the Office of Policy Planning and Evaluation of the FTC: The simple fact of the matter is that economic theory has nothing in it that suggests that vertical integration, either by contract or ownership, is in any general way likely to injure the interests of consumers. 692 antitrust \& Trade Reg. Rep. (BNA) E-11 (1974).

159. See, e.g., United States v. Citizens \& Southern Nat'l Bank, 422 U.S. 86 (1975); United States v. Marine Bancorporation, 418 U.S. 602 (1974); United States v. First Nat'l Bancorporation, Inc., 410 U.S. 577 (1973), aff'g 329 F. Supp. 1003 (D. Colo. 1971); United States v. Falstaff Brewing Corp., 410 U.S. 526 (1973); Ford Motor Co. v. United States, 405 U.S. 562 (1972).

160. An additional 29 gorernment suits alleging violations other than price-fixing involve a variety of offenses in which injurics to consumers are likely to be as uncertain as in those cases discussed above. These alleged violations include: contempt of a prior consent decree or judgment, United States v. Work Wear Corp., 5 TRude REG. Rer. ff 45,075 (Cas. No. 2469) (N.D. Ohio 1975) (disposition noted); conspiracies not to engage in advertising, United States v. American Pharmaceutical Ass'n, 5 Trade Rec. Rrp. If 45,075 (Cas. No. 2492) (W.D. Mich., filed Nov. 24, 1975); conspiracy to eliminate competition in research and development, United States v. Manufacturers Aircraft Ass'n, 5 Trade Reg. ReP. $\uparrow 45,072$ (Cas. No. 2223) (S.D.N.Y., filed Mar. 29, 1972) (disposition noted). Finally, three suits alleged agreements among roofing contractors to limit their guarantees to two years. United States v. Greater Buffalo Roofing \& Sheet Metal Contractors' Ass'n, 5 Trade Reg. ReP. If 45,075 (Cas. No. 2473) (W.D.N.Y., filed Aug. 8, 1975); United States v. Composition Roofers \& Waterproofers Employment Ass'n, 5 Trade REg. ReP. If 45,075 (Cas. No. 2472) (E.D.N.Y., filed Aug. 8, 1975); United States v. Roofing, Metal \& Heating Associates, Inc., 5 Trade Rec. Rep. $\int 45,073$ (Cas. No. 2344) (E.D. Pa. 1973) (disposition noted). 
than 20 of these suits have been brought against groups of lawyers, architects, engineers, accountants, anesthesiologists, veterinarians, and (particularly) real estate brokers. ${ }^{161}$

The fee schedule cases provide a dramatic example of the potential dangers of parens patriae and fluid class suits in circumstances where the equities fail to match the preconceived notions of the proponents of these procedural devices. These cases generally involve small individual businessmen and practitioners, not giant corporations. The defendants are not hardened price-fixers; in many cases the legality of the codes of ethics and fee schedules in question was generally assumed even by lawyers until the Supreme Court ruled otherwise just last term. ${ }^{102}$ Finally, it is highly unlikely that any of these groups of defendants has amassed a "pot of gold" by gouging consumers. As one court noted in approving the settlement of a class action against certain realtors in Alabama that provided for no damage recovery at all, in each and every case where real estate brokerage fee schedules have been enjoined, the effect has been to increase rather than lower rates. ${ }^{103}$ Therefore, it is doubtful that the violations found in these cases hurt consumers at all.

161. See 5 Trude REg. REP. If 45,071-75 (1976) (citations on file with Yale Law Journal). For a discussion of the fee schedule cases, sec Note, The Antitrust Division $v$. The Profession-"No Bidding" Clatuses and Fee Schedules, 48 Notre Dame LAw. 966 (1973).

162. Goldfarb v. Virginia State Bar, 421 U.S. 773 (1975) (minimum fee schedule published by the county bar association and enforced by the state bar constituted pricefixing in violation of $\$ I$ of the Sherman Act). For cases involving other professions, sce United States v. National Ass'n of Real Estate Bds., 339 U.S. 485 (1950); United States v. National Soc'y of Professional Eng'rs, 389 F. Supp. 1193 (D.D.C. 1974), vacated and remanded, 422 U.S. 1031 (1975), on remand, 404 F. Supp. 457 (D.D.C. 1975) (Code of Ethics prohibiting submission of competitive bids for enginecring services held per se violation of $\$ 1$ of the Sherman $A c t)$.

163. See Brohers' Fees Higher Since Price-Fixing Suit, N.Y. Times, Mar. 23, 1975, § 8, at 1 , col. 5. That article noted:

Since 1969, the Justice Department has brought suit against more than a dozen real estate boards across the nation. All of the cases have resulted in consent decrees ending the publication of commission guidelines and in higher commissions.

The Justice Department acknowledges that prices-both in the real estate industry and in other service businesses-have risen in the wake of its price-fixing suits.

Similarly, in Hill v. Art Rice Realty Co., 66 F.R.D. 449, 455 (N.D. Ala. 1974), aff'd, 511 F.2d 1400 (5th Cir. 1975), the court stated that:

[i]n both Atlanta and Memphis, consent decrees prohibiting the maintenance of any recommended fee schedules were entered as a result of injunctive procecdings brought by the Lnited States of America. [The] affidavits reflect that the impact of the rescission of fee schedules in commission rates has been in the opposite direction from what plaintiff insists in his suit, with the rates going up rather than down after the claimed "conspiracy" had been ended by government action.

According to the Times article, the increases in commission rates were substantial and immediately followed the consent decrees in the government suits, indicating that the rise in rates was probably attributable to the removal of the fee schedules. A brokers' lawyer explained the effect of the fee schedules in apparently holding down rates in New 
Nevertheless, real estate brokers in particular have recently been subjected to a number of class suits asserting astronomical treble damage claims, which are particularly shocking in light of the smallness of the businesses involved. In Kline v. Caldwell, Banker of Co., ${ }^{104}$ for example, the representatives of the alleged plaintiffs' class sought to recover $\$ 750$ million from some 2,000 Los Angeles realtors (the vast majority of whom were individuals in business for and by themselves) based upon the claimed use of recommended fee schedules in some 400,000 sales of residential property. In refusing to certify this class, the Ninth Circuit relied on the requirement of fairness in Rule 23(b)(3). ${ }^{165}$ In his concurrence, Judge Duniway pointed out that to allow a class action in Kline would be to create "an overwhelmingly costly and potent engine for the compulsion of settlements, whether just or unjust"; most brokers, he observed, are small businessmen who "cannot afford even to participate in such an action as this, much less to defend it effectively," and who therefore "will settle for whatever amount they can bargain for, and without regard as to whether they are really liable or not." 160

Use of parens patriae and fluid class remedies against such defendants could result in the very unfairness which the Kline court managed to prevent. While it is doubtful that the draftsmen of the proposed parens patriae bills deliberately intended to revoke the "fair-

York City by the fact that the New York board was dominated by building owners. "'Brokers have always had the weakest voice, and attempts to raise fees met resistance." N.Y. Times, Mar. $23,1975, \S 8$, at 10 , col. 2.

Whatever the reason for the price increases, it is clear that these suits were brought against defendants whose prices were lower than those subsequently established by market forces.

164. 508 F.2d 226 (9th Cir. 1974), cert. denied, 421 U.S. 963 (1975).

165. In Kline, plaintiffs brought suit on behalf of themselves and all other sellers of real estate in Los Angeles County, against a realty board and a class of real estate brokers who were members of the board. The court stressed that to permit rccovery would impose joint and several liability for the wrongdoing of the whole class on each of the 2,000 realtors who were members of the defendant class-a result which "would shock the conscience." Id. at 234. For this reason, the court could not "find that under Rule $23(b)(3)$ this class action [was] superior to other available methods for the fair and efficient adjudication of the controversy." $I d$. at 235 . The principle established in Kline was characterized as "the notion of fairness to the defendants" in Marks v. San Francisco Real Estate Bd., 69 F.R.D. 353, 355 (N.D. Cal. 1975). In Marks, the district court applied this "fairness doctrine" in a context where there was no defendant class and therefore were no issues of joint and several liability similar to those in Kline. However, the potential exposure for each realtor was very great due to the "number of plaintiffs and the sum of their individual claims." Id. at 356. The court concluded that this potential liability was so large that to permit the class action to be maintained would contravene basic notions of fairness. But see Knowles v. Tuscaloosa Bd. of Realtors, Inc., 1975-2 Trade Cas. $\mathbb{f} 60,501$, at 67,815 (N.D. Ala. 1975), permitting a class suit against a group of realtors similar to those involved in Kline.

166. 508 F.2d at 238 . 
ness" doctrine articulated in Kline, they have in effect done so by failing to provide many of the Rule 23 safeguards. ${ }^{167}$ The Ninth Circuit's holding in Kline was predicated upon the requirement of Rule 23(b)(3) that a class action be "superior to other available methods for the fair and efficient adjudication of the controversy." 168 Since no corresponding language is included in the proposed legislation now before Congress, the courts in parens patriae suits might be held to lack the power, which the Ninth Circuit exercised in Kline, to prevent unfairness to defendants. ${ }^{169}$

167. One striking feature of the debates on H.R. 8532 was the total failure of its proponents to come to grips with the problems inherent in the elimination of Rule 23 safeguards. Some Congressmen speaking in faror of the bill seemed to be relying for the prevention of abuses on the very elements of judicial discretion which parens patriae would do away with. Representative Badillo, for example, stated:

The issues of potential abuse, class action safeguards, character of notice, mode of aggregating damages and the distribution of recovery are all issues more properly considered by the judicial branch. Rules to meet those objections should be fashioned on a case by case basis.

122 Cong. Rec. H2067 (daily ed. Mar. 18, 1976). Apparently the Congressman failed to recognize that, unlike Rule 23, H.R. 8532 contains no provisions allowing a court to reject parens patriae suits which would result in abuse, injustice, or undue burden on the judiciary.

To the same effect, Representative Mazzoli characterized the fear of abuse as a "myth," citing the fact that the "defendants won" in the Hotel Tel. Charges, Kline, and Eisen cases. Id. at H2068. What Representative Mazzoli failed to recognize, however, was that the reason the defendants "won" in those cases was that Rule 23 contains precisely those provisions allowing a court to reject a proposed class on grounds of unfairness or unmanageability which are so conspicuously absent in the parens patriae bills. See notcs 16 \& 17 supra (discussing In re Hotel Tel. Charges, 500 F.2d 86 (9th Cir. 1974)).

168. FED. R. Civ. P. 23(b)(3) (emphasis added).

169. Proposals to insert safeguards in the House parens patriae bill to avoid unfairness were defeated. See, e.g., 1975 REFORT, supra note 36, at 23-24 (minority views):

The committee rejected an amendment that would have permitted the court to take into consideration the "defendant's degree of culpability, any history of prior such conduct, ability to pay, effect on ability to continue to do business and such other matters as justice may require."

Similarly, as reported in 724 ANTITrust \& TRAde REg. REP. (BNA) A-12 (1975):

A one-page substitute bill proposed by Rep. James R. Mann (D-SC) also was defeated. It would have permitted parens patriae actions only for price-fixing and restraint of trade violations and would not have allowed damage recovery for other anticompetitive activity. Committee Chairman Peter W. Rodino (D-NJ) said the amendment would "destroy the whole concept of the bill," leaving citizens with small damage claims as second-class citizens. Other objections to Mann's proposal were raised, and it was defeated after a short debate.

In addition, see the testimony of David Klingsberg, Esq., proposing that the scope of the parens patriae remedy be limited to direct and proximate injuries to consumers arising from "hard core" violations of the antitrust laws. 1975 Hearings on Parens Patriae Amendments, supra note 40 , at 51,59 .

Finally, on the floor of the House, H.R. 8532 was amended to provide that where damages are "proved and assessed in the aggregate," only single damages may be awarded against a defendant who "establishes that he acted in good faith and without reasonable grounds to believe that the conduct in question violated the antitrust laws." H.R. 8532, 94th Cong., 2nd Sess. $\$ 2(4 D)$ (1975). To ensure further that the fluid recovery provisions of the bill would be invoked only in cases of clear, hard core antitrust 
In short, while the proponents of the parens patriae bills may have in mind their application to cases of hard core antitrust violation by defendants that have unjustly enriched themselves at the public expense, nothing in the proposed legislation so limits state suits or indeed contemplates judicial control to avoid the very real danger of inequity-a danger which is apparent in the kinds of cases that the Justice Department and private plaintiffs are now bringing. ${ }^{170}$

Turning to the remaining 25 retail price-fixing suits, four of these alleged price-fixing in vending machine sales of cigarettes and soft drinks; ${ }^{171}$ four charged local price-fixing conspiracies in retail liquor

violations, another amendment was added making any application of $\$ 2$ (4D) dependent on a "determination that the defendants agreed to fix prices in willful violation of the antitrust law." Id. Hence, as a result of being hastily composed on the floor of the House, the aggregation of damages provision of H.R. 8532 now contains a totally redundant proviso allowing only single damages in cases of non-willful violation which are beyond the scope of the section in the first place. While these amendments would help mitigate the harshness of the parens patriae procedure, it should be remembercd that the maintenance of a class action was found to be unfair in Kline for reasons having nothing to do with proof of damages in the aggregate-a proposed innovation which was not at issue in that case. Thus, the "fairness doctrine" cstablished in Kline could be circumvented cren under amended H.R. 8532 by a state secking to proceed under $\$(4 \mathrm{C})(\mathrm{a})$ as parens patriae, albeit without benefit of the provision for aggregation of damages. Moreover, the Senate bill still would permit treble damages to be recovered in all Sherman Act cases with no mitigation in penalty whatsocrer for persons who, in good faith, did not believe their conduct to be illegal.

170. Representative Rodino, in a statement submitted to the House Rulcs Committee, expressed the hope that the danger of imposing unconscionable liability on innocent businessmen for conduct reasonably thought to be lawful would be avoided by the provision in the bill limiting the availability of the parens patriae remedy to violations of $\S \S 1$ and 2 of the Sherman Act:

The "innocent businessman" argument ignores the fact that the parens patriae remedy would be available essentially only with respect to violations of sections 1 and 2 of the Sherman Act (price-fixing, monopolization and other combinations and conspiracies in restraint of trade). . . . There are, in fact, few if any areas of business activity where the application of Sections 1 and 2 of the Sherman Act is not clearly delineated by past decisions.

Memorandum on H.R. 8532, The Parens Patriac Bill, from Congressman Peter Rodino to House Rules Committee, at 2-3, Feb. 6, 1976 (footnote omitted) (on file with Yale Law Journal).

Unfortunately, this is just not the case. The Kline suit was, in fact, predicated on $\$ 1$ of the Sherman Act; the defendants' adherence to their association's fee schedule was attacked as an alleged conspiracy in restraint of trade. United States $v$. Topco Associates, Inc., 405 U.S. 596 (1972), in which cooperative efforts by small grocers to compete with the large chains were struck down as a horizontal market allocation, was, again, a $\$ 1$ case. Indeed, one of the most persistent charactcristics of modern antitrust jurisprudence has been the Supreme Court's continual extension of $\$ \$ 1$ and 2 of the Sherman Act to new areas of business conduct.

The limitation of the aggregation of damages provision in the House bill to willful price-fixing, see note 169 supra, is, of course, far more significant. H.R. 8532, 94th Cong," 2d Sess. $\$ 2(4 D)$ (1975). To obtain the kind of protection for innocent conduct that Representative Rodino seems to want, however, the same limitation would have to be placed on the availability of the parens patriae action itself.

171. United States v. Georgia Automatic Merchandising Counsel, Inc., 5 Tride RIc. 
sales in Clovis, New Mexico and Waco, Texas; ${ }^{172}$ five charged similarly local price-fixing conspiracies in shoes and women's clothing in Albuquerque and New York City, respectively; ${ }^{173}$ eight involved automobile repair work; ${ }^{174}$ two charged price-fixing on assembled tour packages; ${ }^{175}$ and two concerned price-fixing by a group of gas stations in Jackson, Wyoming. ${ }^{176}$ Surveying this assortment of alleged local violations, almost all involving very small businesses, it would seem that the proposed use of parens patriae and fluid class remedies here is likely to be at best unnecessary and at worst actually detrimental to consumer welfare. The garages, liquor stores, tour coordinators, and other businesses involved in most of these violations are, after all, sufficiently small that the fines of up to $\$ 1$ million provided by present law ${ }^{177}$ already suffice to threaten economic extinction. To the extent that parens patriae gives the states the power to extract

Rer. I 45,073 (Cas. Nos. 2333, 2334) (N.D. Ga. 1974) (criminal and civil actions against almost identical groups of defendants, dispositions noted); United States v. AAV Cos., 5 Trade Reg. Rer. If 45,073 (Cas. Nos. 2302, 2303) (S.D. Ohio, indictment returned Jan. 16, 1973) (criminal and civil actions against the same defendants, dispositions noted). In these cases, the small, unrecorded, cash purchases involved make it difficult, if not impossible, for many consumers to establish individual claims.

172. United States v. Clovis Retail Liquor Dealers Trade Ass'n, 5 Trade Reg. Rer. I 45,074 (Cas. Nos. 2409, 2410) (D.N.ML, indictment returned Sept. 27, 1974) (criminal and civil action against almost identical groups of defendants, dispositions noted); United States v. Colley Enterprises, Inc., 5 Trade REc. Rer. If 45,072 (Cas. Nos. 2257, 2258) (S.D. Tex., indictment returned June 28, 1972) (criminal and civil action against the same defendants, dispositions noted).

173. United States v. Saks \& Co., 5 Trade Reg. Rer. $\uparrow 45,074$ (Cas. Nos. 2411, 2412) (S.D.N.Y., indictment returned Oct. 7,1974 ) (criminal and civil actions against almost identical groups of defendants, dispositions noted); United States v. Wohl Shoe Co., 5 TRIDE ReG. ReP. If 45,071 (Cas. Nos. 2192-2194) (D.N.M., indictment returned Oct. 19, 1971) (dispositions noted).

174. United States v. Northwest Collision Consultants, 5 TRkंADE REG. REP. If 45,075 (Cas. Nos. 2493, 2494) (W.D. Wash., indictment returned Dec. 3, 1975) (criminal and civil action against same defendant); United States v. St. Petersburg Auto. Dealers Ass'n, 5 Trade Reg. Rep. đ 45,072 (Cas. Nos. 2294, 2295) (M.D. Fla. 1973) (criminal and civil action against same defendant, dispositions noted); United States v. Dunn Glass Co., 5 Trade REG. REp. If 45,072 (Cas. Nos. 2246, 2247) (M.D. Ala., criminal information filed May 25, 1972) (criminal and civil actions against almost identical groups of defendants, dispositions noted); United States v. Independent Garage Owners, and Athens Auto. Dealers Ass'n, 5 Tride REg. Rer. f 45,071 (Cas. Nos. 2156, 2157) (M.D. Ga., indictment returned Apr. 8, 1971) (lone defendant in criminal action also one of several defendants in a companion civil suit, dispositions noted).

175. United States v. Hawaii Conference of Tour Operators, Inc., 5 Trade Rec. Rep. If 45,075 (Cas. Nos. 2477, 2478) (D. Hawaii, indictment returned Oct. 2, 1975) (criminal and civil actions involving almost identical groups of defendants, dispositions noted).

176. United States v. Jackson Hole Serv. Station Ass'n, 5 Trade REg. REP. If 45,073 (Cas. Nos. 2323, 2324) (D. Wyo. 1973) (dispositions noted).

177. I5 U.S.C. $\$ 2$ (Supp. IV 1974). Congress recently increased the fine for corporate violators to $\$ 1$ million from the previous $\$ 50,000$ penalty. This amendment also increased the maximum possible jail sentence to three years, and elevated price fixing from a misdemeanor to a felony. Antitrust Procedures and Penalties Act-Expediting Act, Pub. L. No. 93-528, § 3, 88 Stat. 1706 (1974). 
monies from defendants above and beyond the damage recoveries actually proved by and paid over to individual consumers, it of course creates a new, expanded form of monetary penalty. Yet the amount of a fine can generally be varied by a court to take into account the economic situation of the person punished, the seriousness of the offense, and other mitigating or aggravating circumstances. None of these normal sentencing criteria can be considered under parens patriae. ${ }^{178}$

This means not only that the punishment resulting from parens patriae is unlikely to fit the violation involved in any given case, but also that the public may suffer by having businesses (especially small businesses) shut down by excessive penalties, with a resulting loss in competition, in employment, and in the economic well-being of the communities affected. ${ }^{179}$ Indeed, since the sample of cases we have previously reviewed shows that most of the defendants charged with antitrust violations directly affecting consumers are small businesses, the cases in which parens patriae suits are not barred by the impossibility of proving pass-on may well be the ones least likely to serve the public interest. ${ }^{180}$

Regardless of the nature of the defendants against whom these pricefixing suits are brought, there is a host of other problems with the proposed legislation. Many of these problems result from the deletion in the parens patriae bills of the procedural safeguards of Rule 23. For example, Rule 23 would allow a court faced with a gargantuan action on behalf of millions of consumers to deny the class on manageability grounds; ${ }^{181}$ the parens patriae bills, without changing any of the substantive rules with respect to proof of injury, ${ }^{182}$ have no such manageability provision and hence would deprive the court of any escape hatch no matter how trivial the consumer claims or how inordinate the judicial effort needed to adjudicate them.

178. An amendment that would have permitted a court to take such factors into consideration was rejected by the House Judiciary Committee. See note 169 supra.

179. In order to avoid such consequences, several congressional opponents of the parens patriae bills have suggested that more flexible punitive devices should be developed. Representative Hyde, for cxample, argued:

[T]he violation should not go unpunished, but the punishment should be based upon other considerations other than imposing treble damages based upon a fictional computation, but also take into account the economic impact a huge verdict will

have on the industry, the likelihood that imposing this measure of damages may close down the business, put people out of work and accomplish nothing but gratify the political ambitions of some State attorney general.

122 Cong. REc. H2087 (daily ed. Mar. 18, 1976).

180. A proposed amendment that would have excluded small businesses from the scope of H.R. 8532 was rejected. See id. H2085.

181. FED. R. Civ. 23(b)(3)(D).

182. See note 104 supra. 
In addition, while engrafting some of the procedural features of a Rule 23 class action on the parens patriae concept (such as notice and the opportunity to "opt out"), ${ }^{183}$ the proposed legislation fails to provide such basic safeguards as standards to ensure that there is a communality of interest among the class of persons on whose behalf the suit is brought; ${ }^{184}$ that subclasses of persons with divergent interests are separately represented; ${ }^{185}$ that the plaintiff will fairly and adequately protect the interest of those on whose behalf he sues; ${ }^{186}$ and that the plaintiff's claims are typical of those of the class. ${ }^{187}$ Apparently, the draftsmen of the parens patriae legislation fail to recognize that these requirements are of constitutional dimension. As the Supreme Court pointed out in Hansberry $v$. Lee, ${ }^{188}$ procedures that purport to adjudicate the rights of absent parties mark a departure from the general rule of Anglo-American jurisprudence and are constitutionally permissible only where the interests of those not joined are "of the same class as the interests of those who are," 180 and where there is some assurance that the latter will "fairly represent" the absent class. ${ }^{190}$ If these minimum standards are not met, or if the representative parties have "dual [or] potentially conflicting interests," 191 the class action fails to "afford that protection to absent parties which due process requires." ${ }^{102}$ Since often not all of the "natural persons" in a given state will have common interests in a given antitrust litigation, ${ }^{193}$ the neglect in the parens patriae bills of

183. See H.R. 8532, 94th Cong., 2d Sess. $\$ 2$ (4C)(c),(d) (1975); S. 1284, 94th Cong., 1st Sess. $\$ 401(4 \mathrm{C})(\mathrm{b})(\mathrm{I})$, (2) (1975).

184. Cf. FED. R. Civ. P. 23(a)(2),(b)(3).

185. Cf. id. $23(c)(4)$.

186. Cf. id. $23(\mathrm{a})(4)$.

187. Cf. id. 23(a)(3).

188. 311 U.S. 32 (1940), cited by the Advisory Committee Note to Rule 23 for the proposition that class actions are subject to the full requirements of due process. Advisory Committee Note, supra note 3, at 7768.

189. 311 U.S. at 40,41 .

190. Id. at 41 .

191. Id. at 44 .

192. Id. at 45. Similarly, in Graybeal v. American Sav, \& Loan Ass'n, 59 F.R.D. 7, 14 (D.D.C. 1973), the court noted: "Due process demands that the rights of potential class members be protected. These rights can only be protected by adequate and proper class representatives."

193. To take just one example, in any alleged price-fixing conspiracy claimed to affect the price of houses, the first purchaser of a home and any subsequent purchasers will have conflicting positions with respect to the pass-on issue. Similarly, where the proof or effects of an alleged conspiracy are different for different time periods or products, different classes of purchasers may have different interests, for example, with respect to whether to accept or reject a given settlement offer. In yet another case, some "natural persons" in a state may have an interest (e.g., as employees) in the survival of a business threatened by a parens patriae action.

In any case where the "class" of natural persons on whose behalf suit is brought is split by divergent interests, no single representative, including a state attorney general, 
the legal concerns carefully considered by the draftsmen of Rule 23 may well be constitutionally fatal. The same may be true of the notice provisions of the parens patriae bills to the extent they offer less protection to absent class members than does Rule 23. ${ }^{194}$

The pending legislation raises additional constitutional problems insofar as it goes beyond the normal functions of a compensatory remedy and adopts fluid class and parens patriae devices that would permit states to collect and dispose of damage recoveries based on injuries suffered by consumers who do not press their individual claims. Judge Medina, writing for the Second Circuit in Eisen, held the fluid class procedure "an unconstitutional violation of the requirement of due process of law." 195 Former Solicitor General Griswold persuasively argues that, because the states are not the real parties in interest, such litigation does not constitute a justiciable case or controversy within the jurisdiction of the federal courts under Article III of the Constitution. ${ }^{196}$

Finally, the bills suffer from the crucial constitutional defect of conferring on state officials the power to enforce the federal antitrust laws. Existing antitrust treble damage actions, like other private suits under federal law, require the plaintiff to demonstrate injury to him-

can adequately represent all absent parties within the minimum constitutional requirements articulated in Hansberry v. Lee, 311 U.S. 32 (1940).

194. The pending Senate bill departs from the requirement of Rule 23(c)(2) that notice to absent class members "shall be the best notice practicable under the circumstances," and would instead permit notice by publication in a parens patriae suit, unless a court finds such notice to be "manifestly unjust." S. 1284, 94th Cong., lst Sess, $\S 401(4 \mathrm{C})(\mathrm{b})(1)(1975)$. As indicated by the Advisory Committec, however, the notice provisions of Rule 23 are those required as a matter of due process under Mullane v. Central Hanover Bank \& Trust Co., 339 U.S. 306 (1950). Advisory Committec Note, supra note 3, at 7768 . In Eisen v. Carlisle \& Jacquelin, 417 U.S. 156, 175 (1974), the Court cited with approval the holdings in Mullane and Schroeder $v$. City of New York, 371 U.S. 208 (1962), that "publication notice could not satisfy due process" where the names and addresses of the class members were known. In providing for a lesser standard of notice, the Senate bill ignores the controlling constitutional requirements.

The House bill, while recognizing the possibility of notice by publication where appropriate, incorporates the constitutional requirement that "the best notice practicable under the circumstances" be provided in each case. H.R. 8532, 94th Cong., 2d Sess. $\$ 2(4 \mathrm{C})(\mathrm{c})(1975)$.

195. 479 F.2d 1005, 1018 (2d Cir. 1973), aff'd on other grounds, 417 U.S. 156 (1974) ("Even if amended Rule 23 could be read to permit any such fantastic procedure, the courts would have to reject it as an unconstitutional violation of the requirement of due process of law.")

196. Memorandum by E. Griswold on Certain Constitutional Questions Arising with Respect to "Fluid Recovery" Provisions of Title IV of S. 1284 (stbmitted to Senate Judiciary Comm. as part of supplementary statement of Allen C. Holmes, on behalf of the Section on Antitrust Law of the American Bar Association, Mar. 15, 1976; on file with Yale Law Journai). Griswold goes on to argue that fluid recoveries violate due process, and, insofar as moneys extracted from defendants are used by states for public purposes, contravene the Fifth Amendment guarantee against the taking of property without just compensation. 
self and thus involve the enforcement of clearly private rights. ${ }^{197}$ Parens patriae, by contrast, would allow the states to sue to vindicate public rights by in effect imposing fines designed to punish wrongdoers, to force them to disgorge ill-gotten gains, and to deter future violations. ${ }^{198}$ In purporting to grant such enforcement powers to state officials, the pending bills are unconstitutional under the Supreme Court's recent decision in Buckley v. Valeo. ${ }^{199}$ There, in holding that the creation of a congressionally-appointed commission ${ }^{200}$ empowered to enforce the Federal Election Campaign Act violated the appointments clause of the Constitution, the Court ruled:

We hold that these provisions of the Act, vesting in the Commission primary responsibility for conducting civil litigation in the courts of the United States for vindicating public rights, violate Art. II, cl. 2, $\$ 2$, of the Constitution. Such functions may be discharged only by persons who are "Officers of the United States" within the language of that section. ${ }^{201}$

In support of the proposition that only "Officers of the United States" duly appointed by the President may be entrusted with the "administration and enforcement of a public law," the Court relied on the Confiscation Cases, which established that the Attorney General may discontinue litigation even where private parties are empowered to share in the recovery with the United States. ${ }^{202}$ Thus, in Buckley the Supreme Court recognized a constitutional principle implicit in the appointments clause that decisions with respect to the enforcement of federal statutes should be made by "Officers" of the federal executive branch. In that way, there is some assur-

197. See Clayton Antitrust Act $\$ 4$, 15 U.S.C. $\S 15$ (1970):

Any person who shall be injured in his business or property by reason of anything forbidden in the antitrust laws may sue therefor . . . and shall recover threefold the damages by him sustained ....

198. As we have seen, the whole thrust of the parens patriae bill is to punish and deter violators rather than redress any injuries to the states themselves or even injuries to their consumer-citizens, many if not most of whom are unlikely to receive actual monetary compensation. Indeed, the key difference between parens patriae and existing class actions is that the former would allow states to extract moneys from defendants that are not being claimed by the individual consumers actually injured by a violation.

199. 96 S. Ct. 612 (1976).

200. The Commission was to consist of six congressionally designated members (two to be appointed by the President pro tempore of the Senate, two by the Speaker of the House, and, as ex officio, non-voting members, the Secretary of the Senate and the Clerk of the House) plus two members appointed by the President. Id. at 679-80.

201. Id. at 691-92.

202. 74 U.S. (7 Wall.) 454, 461-63 (1868). The Court held that the Attorney General could move for the dismissal of an appeal of an adverse decision in an action to confiscate a former Confederate vessel, despite the fact that an informer was by statute entitled to one-half of the recovery. 
ance that such laws will be administered in the national interest and, if they are not, at least that the officials responsible will be accountable to the President who in turn is politically and constitutionally answerable for the manner in which federal laws are enforced.

Thus, by giving responsibility for bringing antitrust suits to 50 state attorneys general, parens patriae is likely to impede the effective enforcement of the antitrust laws. This shift will make it far more difficult to formulate and implement policies aimed at bringing those antitrust suits that will have the maximum beneficial economic effects. It will also increase the probability that suits will be brought which are harmful to the public interest, since the very granting to the states of the power to bring parens patriae suits for consumers will create pressures on state officials to sue in every colorable case, however questionable the legal or economic rationale for bringing the action may be. ${ }^{203}$

\section{A Suggested New Approach}

Recognizing that in most antitrust contexts parens patriae suits and fluid recoveries are likely to provide ineffective vehicles for helping consumers is, of course, only the beginning of the inquiry as to how the antitrust laws ought to be enforced to protect the consumer interest. To take the example used in the House Report, ${ }^{204}$ even though the task of proving a $\$ 1$ overcharge to each of 50 million consumers may be impossible and impractical, steps could be taken to prevent or halt the violation (and others like it) before any injury was inflicted. That an ounce of prevention in this area is worth many pounds of cure is so obvious as hardly to be worth mentioning; yet the effort to protect consumers under the antitrust laws during recent years has been so one-sided in its emphasis on compensatory procedures that it bears repeating that our first priority should be to deter unlawful behavior that significantly distorts competition.

To the extent Congress has addressed itself to the problem of the prevention of antitrust violations in ways other than as an incidental

203. See, e.g., 1975 REPORT, supra note 36, at 24-25:

We believe that politics and antitrust will not make a happy marriage. The temptations for the politically ambitious to ride into the public eye as its champion against "fat cat" antitrust violators by filing lawsuits to the sound of political trumpets may be too great. Since antitrust cases take years to complete, the politically ambitious attorney general need not fear the embarrassment of a string of losses. In any event, many of the cases will have been undoubtedly settled because of their adverse publicity and their nuisance value. This bill underscores how quickly we have forgotten the lesson many thought we learned last year that politics and antitrust should not be mixed.

204. 1975 REPORT, supra note 36, at 6. See pp. 652-53 supra. 
consequence of the in terrorem effects of parens patriae, fluid classes, and other supposedly compensatory procedures, all of the proposals it has adopted or considered have tended to fall into two categories: stiffer penalties and more money for the enforcement agencies. Congress recently has raised the maximum fine for Sherman Act offenses to $\$ 1$ million for corporations and increased the maximum jail term to three years. ${ }^{205}$ At the same time, it has increased the Justice Department appropriation for antitrust enforcement, thereby making possible the hiring of more attorneys and staff and the commencement of more investigations, civil suits, and criminal prosecutions. ${ }^{206}$

Without in any way belittling the importance of these efforts, what may be most needed at this point to improve antitrust enforcement is not so much additional sanctions, or even further increases in appropriations, but rather the introduction of measures to ensure that the Antitrust Division uses its resources in a manner reasonably calculated to benefit consumers.

That this is not always the case under present practices is suggested by the record of government prosecutions we have previously reviewed. While there is no reason to believe that the relatively low number of Justice Department suits alleging violations directly affecting consumers does not reflect a general predominance of violations at higher distribution levels, it is striking that many of the retailer cases that the Government does bring-such as the fee schedule suits-are often followed by increases rather than decreases in consumer prices. ${ }^{207}$ What is more, the Antitrust Division appears to treat the adverse economic effects of its suits as a matter of considerably less concern than consumer advocates might wish. ${ }^{208}$

205. Antitrust Procedures and Penalties Act-Expediting Act, Pub. L. No. 93.528, $\S 3,88$ Stat. 1708 (1974), amending 15 U.S.C. $\$ 2$ (1970) (codified at 15 U.S.C. $\S 2$ (Supp. IV 1974)). This amendment also elevated price-fixing from a misdemeanor to a felony.

206. Appropriations for the Antitrust Division grew from $\$ 12,836,000$ in fiscal year 1973 to a total of $\$ 27,195,000$ in fiscal year 1976. Pub. L. No. 92-544, Title II, 86 Stat. 1114 (1972); Pub. L. No. 94-121, Title II, 89 Stat. 618 (1975). See S. 1136, 94th Cong. lst. Sess. $\$ \$ 3 \& 4$ (1975), and Senate Comms. ON tIIE Judiciary and Commerce, Report on The Antitrust Enforcengent Authorization Act of 1975, S. Rep. No. 498, 94th Cong., 1st Sess. (1975), which discusses S. 1136 and the bill's enlargement of the enforcement budgets of the Antitrust Division of the Department of Justice and the Bureau of Competition of the Federal Trade Commission. The Senate has approved S. 1136, 743 ANtitrust \& Trade Reg. Rep. (BNA) A-19 to A-21 (1975), and this bill is presently being considered by the House Monopolies Subcommittee. 754 Id. A.4 to A-5 (1976).

207. See note 163 supra.

208. See Brokers' Fees Higher Since Price-Fixing Suit, N.Y. Times, Mar. 23, 1975, $\$ 8$, at 10, col. 4:

For its part, the Justice Department, while conceding that prices have risen, main-

tains that the price level is beside the point.

Joseph Sims, special assistant to the chief of the Antitrust Division, said in a 
In addition, all too often the Justice Department proceeds as though its primary function were to expand the technical, legal scope of antitrust to the maximum possible limit, concentrating on novel areas of application without apparent consideration of the economic consequences or the likelihood that less exotic but possibly more prevalent and harmful practices-such as price-fixing-present greater dangers to the public welfare. This approach is reflected in the Government's merger cases, which have tended to involve smaller and smaller companies and increasingly attenuated theories of the impairment of potential competition ${ }^{200}$ - which have moved, in other words, into precisely those areas where the economic effects of a government lawsuit are most uncertain.

Also indicative of the problems with the Justice Department's enforcement policies is the very large number of cases which have reached the appellate courts in recent years dealing with the application of antitrust to regulated industries. ${ }^{210}$ Here the Government expends precious resources in internecine battles between one federal agency and another. In several recent cases, the Supreme Court has rejected the extension of antitrust to a new area (for example, stock exchange rules fixing brokerage commissions) in order to avoid disrupting regulatory policies adopted to further the congressionally established goal of serving the public interest. ${ }^{211}$ Surely, it is worth considering whether a more open and disciplined decisionmaking process prior to suit might not have brought the Department to the same conclusion on its own-or at least to the view that the question was close enough to warrant an allocation of resources to the stamping out of more unambiguous evils.

The need for procedures to ensure better Justice Department en-

telephone interview from Washington: "It is not a matter of determinative importance whether, following any successful price-fixing prosecution, the price goes up or down. Our interest ... is to attempt to remove whatever artificial restraints a conspiracy has placed upon the ability of the marketplace to set its own prices."

209. See, in addition to the cases cited at note 159 supra, United States v. Federal Co., 1975-2 Trade Cas. If 60,397 (W.D. Tenn. 1975); United States v. Texaco Inc., 5 Trade Reg. Rer. $\int 45,072$ (Cas. No. 2222) (C.D. Cal., filed Mar. 27, 1972); United States v. National Bank, 5 Trade Reg. Rep. I 45,072 (Cas. No. 2220) (N.D. Ga., dismissed Mar. 21, 1972); United States v. Amsted Indus., Inc., 1974-2 Trade Cas. If 75,208 (N.D. Ill. 1974).

210. E.g., Gordon v. NYSE, 422 U.S. 659 (1975); United States v. National Ass'n of Securities Dealers, 422 U.S. 694 (1975); Federal Maritime Comm'n v. Seatrain I.ines, Inc., 411 U.S. 726 (1973); Otter Tail Power Co. v. United States, 410 U.S. 366 (1973); Ricci v. Chicago Mercantile Exch., 409 U.S. 289 (1973). For an analysis of these cases, see Robinson, Recent Antitrust Developments: 1975, 76 Colum. L. REv, 191 (1976); Robinson, Antitrust Developments: 1973, 74 CoLum. L. REv. 163 (1974).

211. See, e.g., Gordon v. NYSE, 422 U.S. 659 (1975); United States v. National Ass'n of Securities Dealers, 422 U.S. 694 (1975). 
forcement policies is heightened by the Supreme Court's increasing adoption of per se rules which keep the Court itself from considering the economic consequences of its rulings in the Government's favor. For example, in United States v. Topco Associates, Inc., ${ }^{212}$ the defendants made out an impressive case that the net effect of their arrangement was to permit them to vie for business with their larger supermarket competitors and thus increase, rather than decrease, competition. The Supreme Court, in striking down the defendants' horizontal market allocations as illegal per se, reasoned that it would go beyond the judicial function and competence to weigh the defendants' claims of enhanced inter-brand competition against the fact of decreased intra-brand competition. ${ }^{213}$ Assuming in light of the Court's opinion that this is so, shouldn't there be at least someone to make a determination as to whether a government victory is going to be good for consumers, competition, and the nation generally? And if the courts are not going to do that job, then shouldn't the Government itself make such a determination based on a reasoned consideration of all pertinent legal and economic factors affecting the public interest?

There would appear to be a number of ways in which existing antitrust enforcement could be improved. For one thing, the Justice Department should be encouraged to bring suits calculated to have major economic effects likely to benefit all groups (including consumers) interested in the proper functioning of the competitive system. Conversely, suits which lack such significance either because of the small size of the defendants, the limited, local nature of their offense, or the problematical economic consequences of the violation in question, should be discouraged.

A second goal toward which Justice Department enforcement efforts should be directed is the protection of the consumer as such. Thus, the detection and prosecution of violations that directly affect consumers should be encouraged and, to the extent necessary, funds should be appropriated specifically for that purpose. In addition, the United States attorneys in the various judicial districts should be authorized to maintain continuous grand jury investigations of pricefixing and other serious antitrust violations that have the most demonstrable, direct, and adverse effects on the consuming public; and the present activities of the Antitrust Division in monitoring prices in various key areas of the economy ${ }^{214}$ should be further expanded as

212. 405 U.S. 596 (1972).

213. Id. at 611-12.

214. See Handler, supra note 2, at 224-25. 
an important early warning system for price-fixing and like violations.

The enforcement policies of the Antitrust Division should also reflect the fact that in cases where the numbers of persons injured are so large and the amounts of individual damage are so small that private suits are unlikely to be maintained, consumers must necessarily depend upon the Government to protect their interests. Even if there is no feasible way in which small private recoveries, after absorption of administration costs, will have any meaningful benefit to consumers, consumer injury can still be prevented through vigilant and effective antitrust enforcement and especially through suits for injunctive relief.

There are several ways to ensure that the consumer interest is better reflected in antitrust policymaking. One is to appoint advisors to both the Justice Department and the Federal Trade Commission who can identify areas of consumer interest and influence the choice of cases to be brought in a way which maximizes benefits to consumers. ${ }^{215}$ Another possibility is to require the Department to prepare a consumer impact statement setting forth an analysis of the likely economic impact on consumers of the Department's enforcement efforts. ${ }^{216}$ Such statements would indicate what portion of government civil and criminal cases materially advance the consumer interest and expose to public scrutiny cases which do not; they would also encourage the bringing of the former type of action and discourage the latter. ${ }^{217}$

One of the great developments in administrative law in recent years has been the attempt to increase both the effectiveness and the responsibility of the various federal agencies through a number of procedural innovations designed to require administrators to articu-

215. Along these lines, the Department of Justice has just created a Consumer Affairs Unit "to assist in coordinating the Department's consumer related activities and programs." The unit will be part of the Office of Policy and Planning in the Office of the Attorney General. CCH Trade Reg. Reports No. 216, at 7 (Feb. 16, 1976).

216. The function of such "consumer impact statements" would thus be similar to that of the "environmental impact statements" required under the National Environmental Policy Act of 1969, 42 U.S.C.A. $\$ \S 4321-4347$ (1976 Supp.), or the "court impact statements" which Chief Justice Burger has suggested be prepared by Congress to assess the effect of proposed legislation on the nation's judicial resources. See Burger, The State of the Federal Judiciary-1972, 58 A.B.A. J. 1049, 1050 (1972).

217. By making the Justice Department's prosecutorial policies more visible, such statements would make possible more meaningful congressional oversight of antitrust enforcement. Public interest groups would also be provided with additional means through which to try to influence prosecutorial policies along lines likely to result in substantial and direct benefits to consumers. Finally, a requirement that policy formulation take place in an open and reasoned manner would provide a form of sclfdiscipline likely to stimulate and sharpen the planning and prosecutorial decisionmaking process within the Department itself. 
late the reasons for their decisions. ${ }^{21 s}$ While the function of the Justice Department is largely prosecutorial, and the discretion of prosecutors is particularly ingrained in our legal tradition, the determinations made by the Antitrust Division as to what kinds of cases to bring also constitute an important aspect of our Government's economic policies. ${ }^{219}$ Hence, it is anomalous for such decisionmaking to be entirely immune from the requirement of open, reasoned consideration which is the hallmark of our administrative procedure in so many other areas. ${ }^{220}$ At the least, this potentially promising vehicle for improving the quality of antitrust enforcement for consumers deserves a good deal more of the attention and creative energy that is presently being squandered on the inherently futile effort to cure the incurable defects of parens patriae and fluid class suits.

Finally, we turn to such cases as may exist where injury to consumers can be proven and individual damages are large enough to make a compensatory remedy meaningful, but where, for one reason or another, it is impractical for consumers to maintain the litigation themselves. In dealing with such cases, there is no reason for the federal enforcement agencies to yield to the states their historic responsibilities for protecting consumers under the antitrust laws. Special legislation could be enacted to allow the Attorney General of the United States to sue under Rule 23(a) as a statutory class representative on behalf of consumers in those cases where he finds that the consumers' claims are significant enough to justify the burden which the suit would impose on the judicial system. In such an action, the court should be empowered to determine not only whether there was an antitrust violation, but also the nature and extent, if any, of the injury to consumers resulting from the defendants' conduct. The court could then, as part of its judgment, lay down rules governing the measurement of consumer damages where the individual consumer has suffered cognizable injury.

218. See, e.g., Friendly, Some Kind of Hearing, 123 U. PA. L. REv. 1267, 1292 (1975). 219. Limitation of the discretion of prosecutors generally has been a subject of increasing comment in recent years. See, e.g., Note, Reviewability of Prosecutorial Discretion: Failure to Prosecute, 75 Coluar. L. Rev. 130 (1975).

Congress recently enacted requirements that Justice Department consent judgments under the antitrust laws be preceded by the publication of a "competitive impact statement" and a 60-day period for the receipt of public comments. The statement and comments are subject to judicial review for a determination of whether the consent judgment "is in the public interest." Antitrust Procedures and Penalties Act, I5 U.S.C. $\$ 16(b)$-(h) (Supp. IV 1974). Since such claborate procedures are required for the Department to settle a lawsuit, at least some safeguards should be imposed at the potentially far more important point when it decides whether to begin onc.

220. For example, in order to help its staff members evaluate how proposed legal procecdings would aid consumers, the FTC has adopted a program of policy protocols 
At that point, the adjudication of individual consumer claims should pass from the courts to an administrative body, such as the Federal Trade Commission. The agency should be empowered to arvard damages in a manner consistent with the court's findings, but only to individual consumers who comply with whatever simplified procedures the agency prescribes within congressionally mandated guidelines. The procedure should be sufficiently simple, however, so that a layman could present his own claim to the agency without having to retain an attorney. While consumers whose claims are not sufficiently large to make it worth their while to comply with even such minimal requirements would, of course, receive no recovery, those consumers whose claims were significant would receive their entire treble damage recovery without deduction for attorneys' fees or for the large costs of administration which would erode individual claims in the proposed legislation..$^{221}$

There are a number of advantages to this suggested procedure. While preserving the fairness and manageability safeguards of Rule 23 , it would allow a broader range of consumer class actions to be brought than at present. The cost of notice to class members would be borne by the federal government, and the FTG procedure for distributing damages would relieve the courts of a major source of manageability problems. The beneficiaries of such litigation would be the consumers who are actually injured rather than the lawyers who all too often are the only ones who profit from a class suit. The approach suggested here would assure consumers of skilled, adequately financed representation in every meritorious case where a treble damage remedy is appropriate. Combined with measures to improve the efficacy of antitrust enforcement from the consumer standpoint, it would accomplish the legitimate objectives of the legislation currently pending in Congress while avoiding the practical and constitutional obstacles which, as of now, make it highly unlikely that parens patriae will ever prove to be a truly effective consumer remedy.

which consist of a series of questions addressed to the staff member. Two of these are now in use in the area of deceptive trade practices, and seven antitrust protocols are planned for the future. 753 Antitrust \& Trade Reg. REP. (BNA) A-19 to A.20 (1976).

221. Under the Senate bill, outside counsel may be retained on a contingency basis, which typically means that the attorney will receive a substantial percentage of the consumers' recovery. While contingency fees are not permitted under the House bill, H.R. 8532, 94th Cong., 2d Sess. $\$ 2(4 G)(1)$ (1975), counsel fees paid out of any settlement recovery would reduce the amount of money available for consumers. Sce 122 ConG. REc. H2086 (daily ed. Mar. 18, 1976) (Rep. Wiggins). 


\section{The Yale Law Journal}

Volume 85, Number 5, April 1976

\author{
JoHN W. SPIEgeL \\ Editor-in-Chief \\ Edward R. MUller \\ Managing Editor \\ Marg L. Brown \\ JOSEPH ISENBERGH \\ EDward D. KLEINBard \\ Glen A. REed \\ Article of Book Review \\ Editors
}

\author{
Ruth N. Glushien \\ Executive Editor \\ MAdeleine A. KLEINER \\ Note \& Project Editor \\ WALTER P. LOUGHLIN \\ Thomas H. Milch \\ GlenN M. Reiter \\ Michael E. Robinson \\ JEFFrey L. Schulte \\ Note Editors
}

T. Alexander Aleinikoff Jerome Davis

LON S. BABBY

George M. Beal II

Tom A. Bernstein

Donald N. Bersoff

J. BrUGe BoIsture

DANIEL H. BoOKIN

Charles G. Buschman

Kenneth S. Canfield

Ralph C. Gavanagh

Benjamin I. Cohen
Business Manager

KeIth P. Ellison

Peter Feuerle ROBERT T. HAAR Garl W. Herstein MARK D. Hoffer Peter R. Jarvis RICHARD A. JOHNSON Peter T. Joseph
Simeon M. KRIESBERG

Albert G. Lauber, JR.

Paul C. Lembesis

Carlos E. MÉndez-Peñate

Robert C. Post

Walter F. Pratt

DeboraH L. Rhode

STEPHEN E. Roth

Jonathan W. Still

SETH P. WAXMAN

ROBERT N. WEINER

Secretaries to the Editors M. Olive Butterfield, Pamela Willmott

\section{Student Contributors to This Issue}

J. Bruce Boisture, The Law Applied in Diversity Cases: The Rules of Decision Act and the Erie Doctrine

Walter F. Pratt, Judicial Disability and the Good Behavior Clause

Seth P. Waxman, Enforcing a Congressional Mandate: LEAA and Civil Rights 